\title{
ARMED CONFLICTS IN AFRICA: FRAGILE STATES AND RISING INSTABILITY
}

This article will analyze the dynamics of armed conflicts in Africa from the perspective of fragile states. The text is divided into two parts. The first part (by $\mathrm{JVdB}$ ) provides a purview of civil wars, border wars and armed insurrections mostly focusing on Southern and Central Africa. The second part (by JR) will take closer look at the risks and dynamics of terrorism, so far limited to Northern and West Africa. All analyzed conflicts focus on the most recent developments of 2016 and will provide short-term and medium-term scenarios on their possible evolution.

In Part 1 will break open the "black box" of these 'failed states' by distinguishing between their structural causes. According to C. T. Call's works, the text will differentiate between a 'legitimacy gap' - the rejection by the political elites and society of "the rules regulating the exercise of power and the accumulation and distribution of wealth;" a 'capacity gap' - the degree that state institutions are unable to provide or regulate the minimal provision of core public goods; and a 'security gap' - The condition when states do not provide minimal levels of security in face of organized armed groups (Call, 2008, 2011; Van den Bosch, 2016).

Part 2 focuses on the basic preconditions for the activities of the major terrorist organizations in Africa. With emphasis on the importance of the north-east and north-west regions of this continent in context of terrorist threats. Hence the initial focus was put on Somalia, which as a permanent fragile state remains under the increased influence of the Jihadist organization Al Shabaab, which is an organization with a high potential for increased capacity in the coming years. Next, was sketched out the situation in Egypt, considering, in essence, the activity of the so-called Islamic State in Sinai Peninsula. In this Analysis it also pointed to the intricate internal situation in modern Libya after so-called Arab Spring and international military intervention, where, despite earlier appearances, the terrorist threat was too much positioned, mostly by comprised to the internal conflict between the different Libyan political parties. Finally, efforts were made to illustrate the current terrorist activity in the Mali area, highlighting the importance of Al Qaeda branch AQIM and the situation in Nigeria where Boko Haram group operates. 


\section{PART I: ARMED CONFLICTS IN AFRICA: FRAGILE STATES, INSURRECTIONS \& BORDER WARS}

\section{Smoldering Civil War in the Central African Republic}

The conflict in the CAR broke out after a loose rebel alliance or northern ethnic groups, Séléka (meaning 'alliance' in Sango) challenged the government of François Bozizé in late 2012, finally overthrowing him in March 2013. The rebel advance was followed by sectarian ethnic cleansing between northern Muslim militias and southern, riverine Christian communities, which in turn mobilized in various Anti-balaka militias. The CAR has followed the path of the DRC, in which entrenched personalist rule has hollowed out the state, resulting in the loss of the state's monopoly of violence over its territory and opening the gates for foreign predation. Elite conflict spilled over into communal conflict, which in turn led to a complete breakdown of the rule of law, leading to the further criminalization of many parts of the state, enforcing local conflicts and creating new ones.

Before losing power, a battered Bozizé had taken on a constructive attitude vis-à-vis the international mediation attempts between his regime and opposition forces. From 2004 to 2008 a wave of conflict and attempted coups had broken out against his regime. State security forces, various rebel groups and road bandits all committed systemic violence against civilians, especially in the northeast. In need of foreign support, Bozizé had agreed to democratize, but did not intend to release power. In 2010 he postponed elections twice, but managed to win $64 \%$ of the vote. The elections were deemed free and fair, despite irregularities, a very low frequency, and the protests of the opposition. When violence broke out once more the international community became more critical toward Bozizé, but more crucial was the loss of Idriss Déby, president of Chad, as his ally. Déby was afraid that Séléka would link up with opponents of his regime residing in the CAR. As he withdrew his troops, the Séléka rebels were finally able to take Bangui in March 2013, forcing Bozizé to flee (Herbert et al., 2013; AIP, 2014; ACLED, 2015).

The CAR has had become an increasingly failing state (Call, 2008, 2011) as the stubborn consequent legitimacy gaps deepened the existing capacity gap and finally led to a severe security gap that even the current transitional government is not able to mend. For its inception, the CAR has been under personalist rule, with only one knows peaceful transfer of power since independence (Ange-Félix Patassé in 1993). The violent sectarian conflict that broke out in 2012 is the culmination of this legacy of structural exclusion and inequality. The country's ruling groups, dominated by ethnic riverine groups until 2003, started as broad ethnic coalitions, but became increasingly exclusive as state resources dwindled and patronage networks shrunk (Cederman et al., 2005).

When Bozizé overthrew the (only) democratic regime of Patassé in 2003, the new ruling coalition was dominated by the Baya ethnic group, coopting some other minor groups from the northern and riverine regions. After Séléka took over in 2013, rebel 
leader Michel Am-Nondokro Djotodia's ${ }^{1}$ main support base were the Muslim Runga, a very small ethnic group (comprising about 21,500 people) that had not been a political force in CAR politics before 2005 (Cederman et al., 2005; CAR CSG, 2011: 42). After taking the presidency, Djotodia disbanded the (predominantly) Muslim rebel movement that brought him to power, letting his militias (among them many mercenaries from Chad and Sudan) to pillage and terrorize the population on a massive scale. Since the population in the southern, riverine provinces was mostly Christian, they set up their own (anti-balaka) militias completing the spiral of violence (McCormick, 2013). As noted in the research of McCauley (2014), sectarian mobilization can be extremely violent is ethnic and religious identities overlap, which happened in case of the Séléka and anti-balaka militias.

Five days after the coup, warring militias left at least 600 dead. In light of this swift deterioration The UNSC remained hesitant to intervene with a multilateral peace enforcement operation, but still the Security Council gave the green light to France, CAR's former colonizer, which was willing to intervene (Resolution 2127, 2013). Operation Sangaris, launched between 5 and 8 December 2013 led to a deployment of a 1,600 French troops to support the 6,000-strong African-led International Support Mission for the CAR (MISCA). Despite the many warning signs, the risk of genocide proved difficult to avert, as the existing UN presence, the $U N$ Integrated Peacebuilding Office in the Central African Republic (BINUCA), was understaffed and not equipped to protect civilians and MISCA experienced delays in reaching full operational capacity. French operations, however, stayed circumscribed to Bangui, and the difficulties immediately encountered by the French troops laid bare the scale of the challenge involved in restoring a modicum of order even in this limited area (Lockhart Smith, 2014: 177-181). In an evaluation of the situation I. Lockhart Smith argued that:

"The adoption of Resolution 2127 meant a rupture with what had hitherto been the status quo. But the absence of US15 and European troops (apart from France, despite approval of a 500-strong EU joint force in January 2014) meant entry into a perilous stage involving a new status quo: a presence in the CAR, but one that, critically, would not necessarily be either sufficient or effective" (Lockhart Smith, 2014: 180).

Enhanced international mediation and intervention became more acute as it became increasingly clear that Djotodia had no control over Séléka. He was pressed to resign by regional leaders, and Catherine Samba-Panza, former mayor of Bangui, was elected on 20 January 2014 to lead the new interim government until the new elections in 2015. Around the same time the EU pledged to reinforce the French presence with an addition 500 troops (Louw-Vaudran, 2014). In September, the AU handed over its peacekeeping mission to the UN. The former's 6,000-strong peacekeeping force, along with 2,000 French troops had struggled to restore order in CAR. With troops from Morocco, Bangladesh and Pakistan, the AU mission MISCA was renamed MINUSCA

${ }^{1}$ Djotodia, born in the remote, impoverished, Muslim north eastern part of the CAR, educated in Russia, had worked in Patassé's government as a civil servant and had been named consul to Nyala in Sudan's Darfur region. From there he was said to have used his time to cultivate alliances with Sudanese and Chadian rebels and guns-for-hire, which would become the backbone of his Séléka alliance (BBC News, 11.01.2014). 
(United Nations Multidimensional Integrated Stabilization Mission in the Central African Republic), subsumed the existing BINUCA, and would increase troops to 12,000, securing better financing and air support for peacekeepers (MINUSCA, 2017; Africa report, 2014).

By December 2014, at least 5,000 had been killed and hundreds of thousands displaced. Ethnic cleansing had driven the population in religious enclaves in order to protect themselves better. As the country is $75 \%$ Christian, the Anti-balaka militias had the advantage of sheer numbers in the southern regions committing a plethora of atrocities on Muslim enclaves. Many factions signed a cease-fire with the transitional government in July 2014, but Séléka had fractured internally, some factions rejecting the cease-fire. They remain in firm control of the northeast, while Anti-balaka militias maintain a grip on large sections of the west. The sudden influx of the displaced to safe zones - some 130,000 in Bangui alone in May - led to a humanitarian emergency. The peacekeeping force could not stop the sectarian violence in the countryside (Moran, 2014).

The situation remained unstable for most of 2015. The UN had not sent its most professional troops. The French presence had been accused (by Finian Cunningham) of being "a fox guarding the hen house" and that their humanitarian deployment was meant to mask Paris' real objective: regime change, that is, the removal Djotodia (The Herald, 2014). In addition, there were allegations of child rape and sexual abuse by French soldiers in the M'Poko refugee camp, and by other European and UN troops. An investigation was launched, but the UN was (initially) criticized for poorly handling the issue. In the end there were no charges for lack of evidence (The Guardian, 29.01.2016; Morenne, 2016). Renewed violence, even in Bangui, paralyzed the humanitarian relief effort in late 2015 (McCormick, 2015), further tainting the whole operation as a "gross institutional failure" (Deschamps et al., 2015). To make matters even worse, the NGO Global Witness issued a report accusing European timber companies (two based in Germany and one in France) of bribing rebel groups to get past road blocks and for protection services in order to maintain their logging activities. These bribes, estimated at $€ 3.4$ million, enabled rebels to continue their operations (African Research Bulletin, 11.08.2015).

In 2016, a new president was elected (Faustin-Archange Touadera), supported by a new constitution (from December 2015), and the US started support for capacity building, ${ }^{2}$ raising hopes for stability (USIP, 26.09.2016). Nonetheless the situation remains dire, according to an international report: Since 2013, an estimated one-third of the population has been displaced. In September 2016, 467,000 Central Africans were still registered abroad with the United Nations High Commissioner for Refugees (UNHCR), and 385,750 were internally displaced persons (IDPs). More than half of the refugees have fled to Cameroon, a quarter to the Democratic Republic of Congo, and the remainder to Chad and the Republic of Congo. The crisis saw the emergence of enclaves, from which trapped populations have been unable to escape for fear of their security. These communities rely on the protection of peacekeeping forces and

${ }^{2}$ Before, they had closed their embassy in Bangui due to the violence and had limited their engagement to trying to hunt down Joseph Kony's Lord's Resistance Army, operating on CAR territory. 
remain in confined camps within which they lack access to basic services. The state has lost control of large parts of the territory, and armed groups have splintered into a multitude of uncontrolled rebel factions, which are increasingly engaging in criminal activities (CAR NRPP, 2016: 1, 6). In the midst of a renewed violent outbreak in late 2016, France declared its peacekeeping mission a success, and stated it would pull back its troops, leaving only a residual force of 350 troops in the country to support the UN (Gramer, 2016).

SCENARIOS - In the short-term, the state-of-affairs in the CAR remains precarious. So far, UN forces have been unable to control or neutralize the violent militias in various remote regions of the country, while their hold on security in Bangui is fragile. Even if positive steps at reconciliation have been taken by the new elected government - initiated by Samba-Panza - the state is non-existent in various parts and its institutions are weak after so many decades of personalist rule. If the government keeps up its efforts at inclusion and reconciliation, and a sufficient foreign peacekeeping and humanitarian presence remains, the state might be able to avert a reescalation of hostilities. Elite conflict over state resources, spilling over to fractured ethnic communities has been the main cause of the conflict (Isaacs-Martin 2016). Alas, the complete collapse of the rule of law has aggrieved rivalling ethnic groups to such a degree that setting up an inclusive government does no longer suffice to bring sustainable peace. Especially since numerous non-state actors got involved as well and are increasingly abandoning their political aspirations for criminal activities. For instance, the Targeted News Service (2014) has identified a conflict within a conflict as widespread crossborder cattle raiding - cattle being the wealth of the poor - has created a new stage for violent competition amongst the impoverished population.

In the mid-term, current peace efforts will be unlikely to succeed if they maintain their focus on the Bangui area and neglect the peripheral areas of the CAR. The state's boundaries are porous and foreign predation can reignite communal conflict. The CAR is located on a geopolitical fault line and will be affected by events in Chad, South Sudan, the DRC, and Northern Uganda. Since progress to counter group grievances, uneven development and abject poverty has been slow, it is likely that regional factors will overtake these efforts and plunge the CAR's once again into high-intensity violent contestation. The present UN deployment, with its mandate extended to 15 November 2017 (Resolution 2301 - MINUSCA, 2017) is not sufficient to counter these risks. Disarmament, demobilization and reintegration programs have not been effective and the ruling CAR leadership has very little interest in implementing these agreements (Mwakideu, 2017). The high number of refugees and internally displaced persons, of which most are unable to return at this point, will add to the future destabilization of CAR's neighbors, and in turn will trigger external shocks for CAR peacekeeping.

\section{Relentless Civil War in South Sudan}

The history of South Sudan is one tragedy after another. After four decades of civil war with the government of Khartoum, the south was finally granted independence by the international community. Alas, in many respects South Sudan was a stillborn and 
failed state when it gained sovereignty. War-torn, with a severe capacity gap, former warlords failed to build inclusive institutions, while an 'oil curse' increased the stakes for political control for all factions. A legacy of weak and extractive institutions swiftly led to a new legitimacy gap, and just two years and five months after becoming the world's youngest state in 2011, a vicious security gap broke out across ethnic lines in December 2013, it's fast escalation taking the international community by surprise.

This article will not expand on the struggle for South Sudanese independence encompassing 20 years of guerilla warfare, claiming the lives of between 1.5 and 2.5 million people, and displacing more than 4 million. The root causes of the war included disputes over resources, the role of religion in the state, self-determination, the grievances over representation due to the distribution of power and the institutional legacy of colonialism (indirect rule) (Zambakari, 2013: 6; BBC, 24.02.2017). In January 2005, the Comprehensive Peace Agreement (CPA) formally ending Sudan's legal authority over its southern territories. The CPA transferred power to John Garang de Mabior, guerrilla leader of Sudan's People's Liberation Movement/Army (SPLM/A), the main participant in the Second Sudanese Civil War (Johnson, 2014: 168). His sudden (and suspicious) death in a helicopter accident in July 2005, three weeks after his inauguration as first vice president of the power-sharing Government of National Unity (GNU), paved the way for elite power struggles to obtain the leadership.

The main two rivals were Salva Kiir Mayardit, Garang's deputy, which assumed the leadership of the SPLM/A and his two constitutional positions; and Riek Machar, occupying the third highest position in the party, which became vice president after Garang's death. Kiir was a veteran guerrilla of the first civil war together with Garang, and now the last surviving founder of the SPLM/A. Machar had joined the movement from a civilian background, broke with Garang in 1991 over personal and ideological differences, failed to create his own movement, and finally could only partly control his rivalling Nuer ethnic militias. He reconciled with Garang in 2002, before the peace negotiations started (Johnson, 2014: 168).

From his new position, Kiir blocked his rivals within the SPLM by barring them from participating in future presidential elections. ${ }^{3}$ For his cabinet he recruited loyalists from outside the SPLM and when dissatisfied factions started forming around Machar and other prominent SPLM figures, he disbanded their party structures and finally even dismissed Machar as prime minister. Machar gain prominence as Kiir's main challenger as he was able to gather these disgruntled, excluded factions and unite them in an unstable alliance (Zambakari, 2013; Johnson, 2014; Giffen, 2016). D. Johnson states that:

"the coalition was more united in its dissatisfaction with Salva Kiir than in support for Riek Machar's ambitions. Many, in fact, were old opponents of Riek, forced into an alliance by Salva Kiir's increasing authoritarianism and intransigence. They in-

3 This alone let to breakaway movements and mini-rebellions in the oil-rich states of Upper Nile, Unity and Jonglei escalating to violent ethnic communal violence. The government responded with heavy-handed disarmament campaigns if militias refused to be reintegrated in the national army. As Kiir had purged the SPLA, the balance of loyalties in the army was now skewed away from longterm veterans of the movement and toward defectors with a history of disaffection (Johnson, 2014: 169-170). 
cluded former governors of Unity, Northern Bahr el-Ghazal, and Lakes states as well as a defeated gubernatorial candidate from Central Equatoria; former ministers and senior figures in the army; members of John Garang's family and one-time close associates of Garang such as Deng Alor Kuol from Abyei. Ethnically they were diverse, coming from the three largest Nilotic groups of Dinka, Nuer, and Shilluk, as well as some Equatorian peoples. Nevertheless, the majority were drawn from Jonglei, Upper Nile, and Unity states, the former strongholds of pro Khartoum militias and Riek Machar's 1990s breakaway group. It was an unlikely alliance and proved to be an unstable one" (Johnson, 2014: 170).

Opposition forces prepared for rallies, but Kiir took the initiative by attacking Machar publically at a National Liberation Council meeting. The opposition denounced the allegation and boycotted the meeting. The trigger that escalated the situation in open warfare was Kiir's decision to disarm of the presidential guard, a combination of SPLA veterans and recently integrated Nuer troops (Johnson, 2014: 171). Fighting between largely Nuer and Dinka soldiers spread to other garrisons around Juba and one day later Kiir announced publically that Machar had been behind a coup-attempt, ${ }^{4}$ sending out security forces for his arrest. Machar was able to flee Juba (Giffen, 2016). Mutinies of largely Nuer units in Jonglei, Upper Nile, and Unity states followed (Johnson, 2011: 171).

In response Machar set up the Sudan's People's Liberation Movement-in-Opposition (SPLM-O) in Jonglei and declared war on the government drawing on recruits from the Nuer ethnic groups. Fighting has been mostly confined to three of the ten states (Jonglei, Upper Nile and Unity), but did spread very fast along ethnic lines, especially ethnic militias committed serious atrocities on the civilian population:

\begin{abstract}
"By January 2015, 1.5 million people had been displaced by violence inside the country, another 490,968 had fled the country, and an unprecedented 100,000 were seeking refuge from violence inside UN bases. Although casualties are difficult to count, the International Crisis Group estimated that 10,000 had been killed in the first four months of the conflict" (Giffin, 2016).
\end{abstract}

When dividing state failure along the three dimensions of a legitimacy, capacity and security gap (Call, 2008, 2011), South Sudan at independence would be classified as war-torn with a significant capacity gap at the moment of the CPA. Garang's death triggered a legitimacy gap, in which kleptocratic elite struggles in combination with high oil-rents for regime insiders, led to violent mobilization across ethnic lines, re-opening the simmering security gap. Between 2005 and 2013, the security gap had been badly addressed: defecting militias were bought off with high salaries and promotions for the officers in exchange for their reintegration in the national army, expanding the force to 240,000 (six times the size since the CPA). As Kiir purged the SPLM/A he fired many SPLA officers in the army, and by 2013 his SPLA faction was a minority within the national force, while at the same time salaries did not reach the rank-and-file (corruption etc.), leading to mutinies. A. de Waal observes that there were cycles of rent-seeking rebellions as army commanders or local political leaders with armed constituents rebelled against the state and then agreed to be reintegrated back into the government for

${ }^{4}$ These allegations were fabricated, no evidence has ever been found nor officially presented (Ylönen, 2014: 468; Johnson, 2014: 171-172). 
higher political and economic rewards; especially before elections or referenda. With oil revenues, Kiir was on top of an enormous patronage system, allowing key supporters to join the kleptocracy, but he was not in charge of them. And when he could not pay them or excluded them, they rebelled to strengthen their negotiating position (de Waal, 2014; Giffin, 2014).

During the outbreak of the conflict, Kiir's SPLA could count on extensive support of Uganda's Museveni, a long-time ally - from his anti-Lord's Resistance Army Unit stationed in the region; and from the SPLA-North in the Blue Nile state and the Darfur Justice and Equality Movement (JEM), the former's ally in South Kordofan. ${ }^{5}$ Surprisingly, the Khartoum government has backed Juba diplomatically at the outbreak of the conflict, offered mediation assistance and was willing to help protect South Sudanese oil installations, as the conflict undermines oil production and Sudan is dependent on its transit fees. Ethiopia has played an active role to find a negotiated settlement as Addis Ababa fears a further escalation. Kenya, concerned about Uganda's extensive involvement, offered moderate support to Kiir's government as well ${ }^{6}$ (Ylönen, 2014: 469-470).

Then UN has been present as well since South Sudan's inception. As their mandate in Sudan ended, their presence was prolonged and their operation rebaptized as the United Nations Mission in South Sudan (UNMISS) with UN Resolution 1996 in 2011. They assisted in implementing the CPA, and aimed to strengthen the capacity of the Government of South Sudan to govern effectively and democratically and establish good relations with its neighbors. To cope with the rapid spread of the violence and the unexpected influx of refugees and IDPs the UNSC temporarily increased the overall troop and police strength of the Mission: The interim troop level of UNMISS was raised to 12,500 personnel and the police component to 1,323 personnel, including appropriate formed police units, through temporary transfers from existing peacekeeping operations through inter-mission cooperation, with matching funds (UN Resolution 2132 in 2013). As the civil war broke out, the UNSC unanimously adopted UN Resolution 2155 in 2014 to reprioritize UNMISS's mandate towards the protection of civilians, human rights monitoring and support for the delivery of humanitarian assistance, and increased the Mission's troop strength to 12,500 and a police component to up to 1,323 personnel. In addition, it created the Intergovernmental Authority on Development (IGAD) task force to support protection of civilians and monitor the cease fire agreement (UNMISS, 2017). Kiir has been adamant in refusing AU troops, potentially including Sudanese soldiers - to bolster the UN mission (IRIN, 27.07.2016).

In December 2016, the conflict has been roaming for three years. Multiple ceasefire and peace agreements (the last one in 2015) have been routinely breached by all warring sides, flouting disarmament and dragging their feet on constitutional reforms (Patinkin, McCormick, 2016), while their undisciplined militias continue to terrorize the population:

${ }_{5}$ The SPLA-North and JEM are former SPLA militias that decided to remain in Sudan after independence. They have been officially disbanded after clashes with president al-Bashir, but still operate (Mahr, 2011).

${ }^{6}$ Both Kenya and Ethiopia have tried to mediate the conflict within the Intergovernmental Authority on Development (IGAD). 
"Apart from mass killings, 1.87 million civilians have been displaced internally to overloaded camps, placing excessive burdens on shelter, health care, sanitation, water, and food services. 1.1 million civilians have sought shelters as refugees in neighboring countries, mainly Uganda. Food insecurity has reached an unprecedented high; 4.8 million South Sudanese, roughly more than a third of the population, are facing severe food shortages. [...] The absence of clean water and proper sanitation has led to re-emergence of cholera outbreaks. [...] Children, in particular, are severely affected by the conflict; it has been estimated that 3.2 million children under the age of 18 years are affected. 16,000 children have been recruited by military forces, and they are increasingly susceptible to detention, exploitation, physical violence, psychological trauma, and sexual assault. 13,000 children are missing, separated from their families, or unaccompanied" (Abu-Zaid, 2017).

Last July (2016) Riek Machar's troops managed to fight their way to the forests near Juba resulting in heavy casualties. However the SLPA succeeded in chasing his militias from the capital southwest through Yei and into the neighboring DRC. Citizens of Yei, which is ethnically diverse, but had remained peaceful so far - were subjugated to ethnic cleansing, indiscriminate killings, gang rape as SLPA troops hunted down Machar. So far, violence continues in the area (Miles, 2017; Sudan Tribune, 30.07.2016). The conflict remains complicated due the amount of foreign predation and spoilers. The PRC for instance, protecting its oil interests, suddenly had to deal with two Sudans in 2011, with most of the oil deposits in the south. The PRC has mostly been unwilling to intervene in Sudanese affairs, but as civil war broke out in 2013 this has led to a situation where the PRC has been providing arms to both Sudans, since it was unwilling or unable to rein in its own (Chinese) arms dealers, such as Norinco. Since Khartoum has been supporting Machar's rebels (as it did before with the Yau Yau rebellion), Chinese arms have been provided to opposing sides (either directly by the PRC or indirectly through Khartoum) (IRIN, 27.07.2016). This also shows that Sudan is playing every card in its hand to ensure it has influence in South Sudan, as it still has major stakes in the boundary delimitation and disputed oil fields (Ferrie, 2016; O'Grady, 2015).

SCENARIOS - There are few indicators that violence will abate. The causes of the conflict are the legitimacy gap caused by Kiir (Biar Ajak, 2015), resulting in a new security gap as Machar set up the SPLA-O to overthrow him. The country's capacity and security gaps had not been sufficiently addressed by the kleptocratic oil-regime in Juba after independence (de Simone, 2013; Munive, 2014). New institutions were weak and meant to extend patronage along ethnic lines, not to be redistribute or inclusive, resulting in inter-ethnic animosities and struggles for state resources (Zambakari, 2013). Without such institutions, ethnic groups like the Dinka and Nuer, but also the Aguok, Apuk and Kuac will continue to negotiate balances of power through violent conflict at regional and local levels. If one group became advantaged, others would take up arms to restore the power balance (Pendle, 2014).

In the short-term, President Kiir - even when increasingly criticized by the international community - has no attractive exit-option for the SPLM/A. In absence thereof, he will continue to fight challengers as long as he has the military clout to do so. At the moment, Museveni's support is crucial and has emboldened him to refuse AU intervention and defy demands for an inclusive peace process and political reforms that might result in him losing power (Ylönen, 2014: 471). An impatient US wanted to im- 
pose more sanctions, but an adamant Russia and PRC have blocked this in the UNSC. The PRC is still Juba's greatest diplomatic and economic ally and wants to stabilize the conflict while not antagonizing Kiir's regime or its Sudanese partners. This balancing exercise has been most difficult for Beijing and - contrary to its bilateral habits - the PRC even engaged in multilateral frameworks and (uniquely) sent troops to the UN peacekeeping Mission (Vasselier, 2016). Nonetheless, Chinese support for Kiir diverts international pressure on his regime and their attempts to strike a balance between their allies' interests makes progress too slow.

The mid-term perspective is equally grim. Even if Machar would be defeated militarily, the ruling regime of Kiir does not have the legitimacy to continue its rule over South Sudan. Rival spoilers (like Kampala and Khartoum) and the abundance or arms will continue to brew a violent mix as grievances among ethnic groups are peaking due to the humanitarian horror and famine. The only way to divert South Sudan from more future civil war is to create an inclusive transition government, cease using oil-rents to bribe rebel groups back into the fold, but on the contrary deter them from taking up arms, and use the oil-wealth to start addressing the capacity gap. This is highly unlikely as Juba's even has enemies beyond its disputed borders and keeps up its current military budget in order to extend patronage and ensure regime survival. Anyway, oilwealth has never been conductive to mend exclusive state institutions, but enhances uneven development and authoritarianism instead (Guliyev, 2014).

\section{The Niger Delta Cyclical Conflicts}

West Africa in 2016 has also seen a resurgence on the Niger Delta Conflict in 2016 after President Muhammadu Buhari won the 2015 elections. His predecessor, Goodluck Jonathan, originating from the Delta himself, had managed to broker a peace deal with militants, which now has collapsed again (BBC, 28.10.2016). The conflict has a long legacy, tracking back to the Biafran secession and the brutal repression of the Ogoni protests under Sani Abacha in the mid-1990s. Uneven development, pollution by spilling and flaring, and the 'oil curse' have made the Niger Delta the epicenter of domestic conflict. It stretches across five littoral states and six internal landlocked ones encompassing about 20 million impoverished villagers and shantytown folk (Clarke, 2010: 89; Oduah, 2016). They have struggled for autonomy, equal distribution of oil revenues, environmental and social justice from the federal government and against land grabbing since the 1950 s. The Niger Delta produces about $90 \%$ of Nigeria's crude and accounts for roughly $70 \%$ of government revenue (totaling around $\$ 80-90$ billion in 2012 and 2013). People are aggrieved that such revenue is not reinvested in their region. They consider oil money as their birthright and feel they have a right to its wealth. Instead they suffer the costs of severe environmental degradation (Oduah, 2016). Historically, numerous groups have taken up the cause of the Niger Delta in one form or another, with various programs of contention ranging from peaceful petitions to pipeline sabotage and assassinations. However since 2006 violence have flared up again. As of 2016 there were five militant groups, the most prominent one being the Movement for the Emancipation of the Niger Delta (MEND). One of the new groups 
is the Niger Delta Avengers (NDA), which are responsible for various acts of sabotage since March 2016 (Muvunyi, 2016).

The Nigerian federal government was running a Presidential Amnesty Program (PAP) since 2009. It is being continued today, but Buhari's background (a Muslim from the north) and his decision to slash funding for the program (by about $70 \%$ ), revoking some security contracts, and scrapping the plan to build a new university, has made Delta inhabitants suspicious of his commitment. They feel that they are being punished for supporting his electoral challenger (and incumbent) G. Jonathan in the last elections (Oduah, 2016). The NDA was one of the first to open hostilities and through pipeline sabotage demanded concessions from the state. A ceasefire agreement was signed in August 2016, but soon after, new militias, like the Niger Delta Greenland Justice Mandate formed and started operating independently (Uldom, 2016). The PAP shows that granting amnesties to violent militias can be effective, but if it is the main or only method of coping with violent insurrections, rent-seeking groups will corrupt the co-optation mechanism and create new groups to commit acts of sabotage just in order to be paid off. The MEND has fallen into this pattern in 2009 (Dickinson, 2009), the NDA did in 2016, and new groups will follow.

SCENARIOS - As there have been serious disruptions in Nigeria's oil production, the government has agreed to invest $\$ 10$ billion to build infrastructure, including roads and railways, and to tackle widespread poverty in the region (BBC, 2.10.2016). However, without any commitment to political settlement on the rebels' demand that the Niger Delta receive a greater percentage of the country's oil revenues. Nor has there been any effort to stem the local corruption that enriches local officials at the expense of pretty much everyone else and diverts huge development funds from reaching the Delta. Without such improvement, the only short-term scenario will be more or the same - that is - cyclical local rebellions and attacks on infrastructure, keeping the state revenues from production hostage in exchange for immediate pay-offs (see also: Dickinson, 2009). If the militant groups are payed off, new ones will appear in the blink of an eye, as the structural causes of the militancy are not removed, and, on the contrary, the PAP provides incentives to resort to violence.

A mid-term scenario is hard to predict as Nigeria suffers from the 'oil curse' (Guliyev, 2014) and is unlikely to democratize and become more inclusive and less corrupt. These exclusive political and economic structures are maintained by the oil revenues, making subsequent regimes unaccountable. This state-of-affairs, in turn, recreates these same structures. The Boko Haram insurrection can likewise be traced back to the same structural causes of horizontal group grievances ${ }^{7}$ and uneven development. In absence of any other factors, the mid-term scenario, alas, might be slow progress in providing infrastructure and government services to the region as the federal government understands that withholding these will result in an even more fertile breeding ground for armed militant groups. Nonetheless, progress is likely to be slow and in absence of a political agreement to redistribute rents, violence will not disappear altogether.

7 Socioeconomic 'horizontal inequalities' (or inequalities among identity groups) contribute to violent political mobilization (Stewart, 2012: 93-103). 


\section{Festering Border Disputes}

Due to the colonial legacy, Africa has known a whole array of border disputes. As - especially offshore - oil extraction progresses some of these have become salient again, and have flared up in recent years. Examples of those oil-related maritime disputes are currently undergoing between the Ivory Coast - Ghana, Kenya - Somalia, Congo (Brazzaville) - Angola, Gabon and Equatorial Guinea, and Malawi and Tanzania (over oil deposits in lake Malawi/Nyasa). Most of them are brought to the AU or International Court of Justice (ICJ) or are peacefully resolved bilaterally, since warfare would disrupt production, in which all involved parties lose (Africanews, 2016; Malek, 2016; Okello, 2016; Oilreviewafrica, 2016; Salau, 2016). This is a break with the past, where some of these disputes did escalate into violence, like for instance the Sand War between Algeria and Morocco in 1963, or the Petrol War between Guinea-Bissau and Senegal, or the conflict over the Bakassi Peninsula between Nigeria and Cameroon (1990s). In those cases, extraction had not yet or barely begun, and therefore could not be disrupted.

Uncertain land borders and staunch sovereignty do not go well together. Even the changing of the Akanyaru riverbed over time since 1965 (due to siltation and flooding caused by heavy rainfalls), altering the border between Rwanda and Burundi, can create cause for conflict if there is no political will to play ball (The East African, 9.01.2017). In general, land border disputes (excluding resource wars) have escalated to open warfare only in one region: the Horn of Africa, even when there were twice as many in Western Africa. M. Kornprobst (2002: 367) has explained this by looking at the status of Ethiopia, which is considered a 'colonial power' in the eyes of Eritrea and Somalia, leading to a variation in their adherence to the 'territorial integrity norm,' which other Sub Saharan states do share (since none considers the other a colonizer), preventing violent escalation.

The Eritrean-Ethiopian border war, a remnant of Eritrea's 30-years war for liberation, followed by their high-intensity interstate war from 1998 to 2000 (killing 100,000), did flare up violently on 12 June 2016, resulting in hundreds of casualties. Cynical analyses that both parties initiated the conflict to mask internal human rights violations aside, the conflict probably escalated due some provocation on the ground as the border is heavily guarded on both sides (Wrong, 2016; Gaffey, 2016).

The Sudan-South Sudan share a border of 2,010 km and still have no agreement over its final delimitation. Both countries have repeatedly committed themselves to the establishment of a Safe Demilitarized Border Zone (SDBZ), but the border remains militarized and trade is disrupted. Especially northern pastoralists who seasonally migrate into South Sudan continue to be harassed on both sides of the border. Since South Sudan's independence in 2011, the border has been marked with clashes since both the SPLM/A and the al-Bashirs's National Congress Party (NCP) have attempted to gain territorial advantages on the battlefield that can later be translated into gains at the negotiating table.

When it comes to South Kordofan and the Blue Nile regions, they had been on the frontline of the Sudan Civil Wars, and now continue to fight for autonomy and politi- 
cal reform. Both regions are split between communities wanting to join Khartoum and Juba respectively. Especially, but not exclusively the large Nuba population in both regions identify with the latter (Insight on Conflict, 2009). In essence the conflict in both regions is a continuation of the Sudanese Second Civil War (1983-2005) as both areas were given the (vague) right to popular consultation during the CPA, and both have suffered social, political, and economic marginalization even since. Fighting broke out when the Khartoum demanded that all SPLA forces in the two areas fully disarm by 1 June 2011, before the CPA implementation deadline (De Alessi, 2015). Khartoum has responded by aerial bombings and ground offensives, which have not ceased since 2017.

After a 2009 referendum, the oil-rich area of Abyei awaits a referendum to decide its fate, but its biggest oil fields have been granted to Khartoum. One of the local communities, the Ngok Dinka, have launched their own referendum in October 2013, voting to join South Sudan, but the result has not been internationally recognized. Disagreements over who is eligible to vote continue, and boycotts from other communities make the results invalid (Insight on Conflict, 2009; HSBA, 2015).

SCENARIOS - In the short or mid-term it is unlikely that the situation will improve between Ethiopia and Eritrea, and future escalations are possible and likely, since the conflict has been entrenched for decades, and both regimes would lose face domestically if they would abide by earlier rulings from the border commission in The Hague. None of the two authoritarian states can stand to lose more legitimacy in this regards and in addition, the Asmara regime does stand to gain by keeping the conflict 'lukewarm,' since it is their foremost excuse to keep up their obligatory military service, effectively their main repressive control element to keep to Eritrean population in check, resulting in systematic enslavement of their population. Without regime change at least in Eritrea, one cannot expect an improvement of this situation in the near future.

A similar conclusion can be drawn for Sudan-South Sudan's border disputes. As the border zone contains oil deposits and agricultural land, and the groups living on the territory switch alliances regularly, there is no hope for an easy solution. The lack of progress in negotiations, the effective failure of the CPA, despite diplomatic statements to the contrary, is eminently productive for Khartoum, which in the meantime can collect the totality of oil revenues from deposits in Abyei, while influencing South Sudanese politics through South Kordofan and the Blue Nile region. So the current, uncertain state-of-affairs are far better than any of the diplomatic proposals currently on the table (HSBA, 2015). Any agreement on a common border will require both states to make substantial compromises. It seems likely that, if the 1956 border is adhered to, Sudan will lose Kafia Kingi and South Sudan will lose the 14-Mile Area. Such losses risk upsetting communities that constitute powerful political constituencies for the NCP and SPLM/A, respectively an it turn for al-Bashir's and Kiir's personalist power coalitions. If these break down, so might their regimes. In this context, both sides have every reason not to agree on a final border, which allows them to placate groups whose support they can ill afford to lose at a time when both regimes face various internal crises (Craze, 2014: 15-16). 


\section{Pockets of Regional Insurrection}

Sub-Saharan Africa is also the arena of various regional rebellions, great and small, new and old, which flare up at various intervals. A full exposition on their origins and dynamics is beyond the scope of this article, but in all cases it is important to highlight that since their structural causes (uneven development, discrimination and government-sponsored retaliation (either directly or by proxy through local (ethnic) militias), and inter-group grievances) have not been addressed, nor can one expect a peaceful resolutions of these conflicts in the near future.

DARFUR - notwithstanding its disappearance from the global headlines since the government's genocide, the Darfur region in Sudan is still not at peace (Insight on Conflict, 2009). In 2014 it experienced the highest levels of violence since 2004, nearly half a million people were displaced. Al-Bashir has become desperate to end at least one of the three rebellions in his country, so - as before - his troops have been working in concert with Arab militias to attack the rebels, imposing arbitrary violence and ethnic cleaning on the population (The Guardian, 2.05.2017). The latest assault started in May 2016 (Reeves, 2016): A large-scale military offense in Jebel Marra was followed with chemical gas attack in September, killing hundreds (Rothwell, 2016). With Russia and the PRC blocking sanctions against Khartoum, it is unlikely the international community will be able to put much pressure on the regime. In addition, in order to stem the influx of refugees, the EU has reached out to al-Bashir to monitor Sudan's borders in exchange for EU funds. Such conflict policy agenda toward Khartoum makes a strong condemnation of the Darfur crisis even more unlikely (Malik, 2016).

CONGO (Brazzaville) - in the Republic of Congo, the so-called Ninja-rebels have resumed activities after their opposition candidate (Guy-Brice Parfait Kolélas) lost to the incumbent, dictator Denis Sassou Nguesso in the March 2016 elections. Historically, the militia had rebelled in support of Kolelas' father (Bernard), which fought against Nguesso's Cobra militias during the 1990s struggle for power and subsequent coup d'état. B. Kolélas fled the country afterwards and died in exile in France in 2009. During his exile, the Ninjas were commanded by the messianic, Frédéric Bintsangou, known as 'Pastor Ntoumi.' However the conflict relocated to the Pool province in southern Congo (Kolélas' birth region) after Nguesso took power. It is obvious that the political deal with the government in June 2008 has broken down now and that the early progress of National Program of Demobilization, Disarmament and Reintegration (NPDDR) is being reversed. After sporadic incidents in the 2000s, escalating violence has displaced some 13,000 people in the Pool province, disrupted their health care and education services. In addition, violence has already made residents miss one harvest and makes them unable to plant their crops before the rainy season, raising fears of famine among the IDPs (The Japan Times, 3.10.2016; Buchanan, 2016; UNHCR, 2016).

DRC - in the DRC likewise elections - or at least their unlawful postponement - have made old conflict resurface. J. Kabila's stubborn determination to hold onto power beyond his legal mandate, have triggered protests in Kinshasa and many other towns. As insecurity and anti-regime contention spread over the war-torn DRC with its deepen- 
ing legitimacy gap, M23 rebels ${ }^{8}$ from refugee camps in Uganda flooded back to eastern Congo (The East African, 21.01.2017). And a new rebel group (the Kamuina Nsapu militia) has emerged in the Kasai region at the moment of writing (BBC, 24.04.2017; Clowes, 2017). 57 years of civil war, warlordism and personalist rule will continue to spawn rebellions if the DRC's legitimacy and capacity are not addressed. The continuation of the former precludes the improvement of the latter, and the situation is most precarious due to continues foreign predation on Congo's resources in the east.

ANGOLA - in Cabinda, the Front for the Liberation of the Enclave of Cabinda (FLEC) has also renewed its activities in August 2016, bringing the total death toll to 40 casualties from clashes between the FLEC and Angolan government forces. FLEC demands Cabinda's independence since it accounts for half of Angola's oil output. They have reasserted their demands since the death this year of its 88 -year-old founder, Nzita Tiago, in exile in France. The rebels, however, do not have the ability to affect oil output in Angola, since nearly all extraction happens offshore. For obvious reasons, Luanda will never part with its exclave. So low-intensity conflict is expected to flare up from time to time in the future (Reuters, 1.08.2016, 8.08.2016).

SENEGAL - the conflict in Casamance (south Senegal, separated by the Gambia), has faded down after Movement of Democratic Forces of Casamance (MFDC) declared a ceasefire in 2014 (BBC, 30.04.2014). The recent removal of Gambian dictator Yahya Jammeh by ECOWAS forces, might contribute to stability in this region. Since Senegal's relations with Guinea-Bissau also have improved, most foreign support for the MFDC has dried up, and the rebel groups' cannabis trafficking is more a criminal enterprise than the movement's bread basket. (Although they still facilitate and tax the contraband flows, the revenues are too small for sustained armed rebellion in the mid1990s.) By the 2000s, financial and material commitments from Dakar to incentivize peace have had the opposite effect, preventing incentives to sustain the conflict for the benefits of government financing. Enhanced cooperation between Senegal, Barrow's new democratically elect government in the Gambia, and Guinea-Bissau are likely to keep violence down. There exist fears that the cocaine trafficking - of which Bissau is the continental hub - might reach Casamance due to its porous borders, but so far this is not the case (Zartman, 2016).

\section{PART II: THE TERRORISM THREAT IN AFRICA IN 2016. MAJOR DETERMINANTS \& PERSPECTIVES}

\section{Permanently Unstable North, South, and East Africa}

The situation in North Africa in 2016 was permanently unstable mainly because of a correlation of three major factors, directly connected to some actions that the state and non-state actors had taken. The first factor was linked to the high risk of activity of various terrorist organizations, like Da'ish (the so-called Islamic State) or those which

\footnotetext{
${ }^{8}$ Named after the March 232009 peace agreement, also known as the National Congress for the
} Defense of the People before splintering into various fractions. 
still have some relationship with classical Al Qaeda. The second factor was strongly related to the internal destabilization of states like Libya or Egypt due to their complicated political situation, which had a source in the trends that had been started in the period of the so-called Arab Spring. The third of the aforementioned factors was the potential threat of rivalry between some of the major states of the region, mostly Algeria and Morocco, which might have had an impact on the onset of the regional conflict. This analysis will focus on such matters and, simultaneously, attempt to present possible scenarios of development in the selected states.

\section{Al Shabaab in Somalia}

Since the 1990s, the Horn of Africa is one of the most turbulent regions of the world where the major security challenges intersect: from a permanent destabilization of the central government in Somalia and the existence of local separatist movements in the regions of Puntland or Ogaden and almost fully independent Somaliland, to piracy in the Gulf of Aden, a famine threat among people who lived in this region and, of course, terrorism. All of these happened mainly due to the internal situation in Somalia, which ranked first in the 2016 Fragile State Index (Found for Peace, 2017) and became a general source of destabilization for other states, such as Kenya, Ethiopia or Eritrea. For a fuller picture of this region, it should be mentioned that Somalia has been listed in the top ten of the most fragile states in the world since 2006. Nevertheless, it is also important to pay more attention to the operations of one of the most effective and strongly present Islamic Jihadi terrorist organizations called Al-Shabaab. The name of this structure stands for "The Youth" and it was coined around 2006, directly as a result of the Ethiopian military intervention in Somalia (BBC, 9.12.2016). The aim of this intervention was to overthrow the radical Islamic Courts Union's (ICU) power in Somalia and to retake control by some Somali antiterrorist fractions supported both by the United States and the most influential regional actors, carried out with the aforementioned Ethiopia. This successfully military operation ran by external forces ended in 2009 and was replaced by the UN peacekeeping operation AMISOM, which was officially launched in 2007 and has been operated in Somalia ever since.

However, the strategic victory over the conventional powers and forces of the ICU has left an enormous void of space for other forms of resistance by Somali Islamic radicals to fill. Because of that, a major youth fraction from the former ICU decided to start an independent long-term partisan warfare; as a result, a wave of terrorist attacks against the targets, located not only in Somalia, followed. Al Shabaab concentrates their actions within Somalia where the governmental forces in Mogadishu and the AMISOM units have never gained full control over the situation. Almost since the beginning, Al Shabaab has been the symbol of terrorism in East Africa, carrying out a lot of minor and major terrorist attacks in 2006-2016 (Sky News, 2.04.2015). One of the most publicized was the one in the Kenyan capital city of Nairobi in 2013 when an Al Shabaab terrorist group stormed the West Gate shopping mall and killed or seriously injured several hundred innocent people. It is necessary to underline that this situation in Kenya has sparked a worldwide discussion about the security in shopping 
malls in the face of a danger of 'active shooter' scenarios. Structurally, Al Shabaab is still a part of the global Al Qaeda's network. In 2008, the then leader of Al-Shabaab, Ahmed Abdi Godane, vel "Mukhtar Abu Zubair," pledged allegiance to Osama bin Laden. Moreover, in 2012 Ayman al-Zawahiri declared that Al Shabaab had formally joined Al Qaeda; this was stated after a video release in which Abdi Godane pledged full allegiance to the successor of bin Laden (Horadam, Cleaves, Sorhaindo, 2015). After the creation of the so-called Islamic State in Syria and Iraq, they rejected joining this new organization and even initiated some brutal actions aimed against the Somali Abu Bakr al-Baghdadi supporters.

At the beginning of 2016, Al Shabaab was mostly focused on a kind of a twopronged strategy. The first goal was to secure their stable position of an official ruler in some of the controlled regions in the South and North of Somalia. Even though they were pushed out of the cities, the stabilization of the sanctuary in rural regions gave them an opportunity to plan some further attacks against AMISOM and the governmental forces. At the same time, they intensified a campaign of typical terrorist attacks, mostly in some urban areas. Of course, the potential destabilization of the situation in Mogadishu was their main aim, as a symbol of the ineptitude of the new government, supported by African states and the West. For this purpose, in January they attacked e.g. a very popular Beach View café, located at the Lido beach, using a combination of bombs and shooters to kill and injure as many as they can. It is necessary to highlight that this attack against a café was also a symbol of a new enlargement of a list of potential targets for Al Shabaab in Somalia. Previously, the terrorists mostly tried to threaten hotels or some strategic public buildings (Mutiga, 22.01.2016).

After that, in 2016 multiple other attacks followed, aimed at a broad spectrum of targets located mostly in the capital city of Mogadishu. An evaluation of the organization's capabilities at that time shows that an assault against the SYL hotel in February was definitely symbolic. Although the security forces managed to stop a suicide bomber and gunmen at a checkpoint before they could reach the above-mentioned hotel, Al Shabaab signaled that they possessed the ability to organize more attacks even in a close proximity to the most secure presidential palace. Terrorists repeated such a tactic in June 2016 when another hotel, Nasa-Hablod, became a target of a coordinated strike by a vehicle-borne, improvised explosive device - VBIED, and a group of shooters (The Guardian, 25.06.2016). Like in the West Gate case, all terrorist attacks against hotels in 2016 in Somalia prompted an important discussion about the level of security in the most well-known tourist locations in East Africa, Kenya in particular, where Al Shabaab has some influence not only in the border region but also in some major cities. Of course, Kenyan intelligence and security forces carried out numerous operations against recruitment and logistic cells of this terrorist organization on their own soil in 2016, to prevent this threat.

From the global perspective on the terrorist threat, another significant case was the attack onboard the Daallo Airlines Flight no. 159 in February 2016. An Airbus A321-111 on route to Jeddah in the Kingdom of Saudi Arabia took off from the Mogadishu International Airport in Somalia. The flight was never completed because of an explosion onboard. The aftermath investigation of this incident brought an alarming hypothesis that the explosive device was built into a laptop computer. Probably, the bomb was 
so sophisticated that the terrorist could carry this item past the X-ray machines at the Mogadishu airport. This might be a clear evidence of a far-reaching cooperation between Al Qaeda of the Arabic Peninsula (AQAP) and the Somali Al Shabaab, regarding explosive devices construction (Kriel, Cruickshank, 12.02.2016). This proves Al Shabaab is an organization which focuses not only on internal and regional issues.

However, an even greater risk of destabilization in Somalia in 2016 came not from a terrorist tactic but rather conventional attacks and raids of the Al Shabaab paramilitary units outside of Mogadishu. AMISOM and the newly trained Somali National Army - SNA - pushed Al Shabaab away from its major strongholds owing to better equipment, air support etc. But, since 2016, it has become apparent that the strategic initiative has weakened and the military operations have lost their impetus. This happened not only because of the weakness of the Somali government and its armed forces but also due to the differences between AMISOM forces and Ethiopia's or Kenya's military and political leaders (Meservey, 2016). It is worth noting that in 2016 the problem of financing the presence of multinational forces in Somalia became more visible. For instance, at a meeting of the UN Security Council on 19 May, 2016, President Uhuru Kenyatta said that AMISOM was not receiving the resources and equipment it needed to carry out its mandate. He said it was not his government's responsibility to fill the funding gap (Muvunyi, 30.05.2016). Each weakness was militarily and politically used by Al Shabaab to expand the controlled area. This was evident at the beginning of 2016 when the control over a large territory and groups of cities like Dayniile, Tooratorow, Yaq Bari Weyne, Buufow, Ababay, Qoryooley, Awdheegle or Golweyne has been taken.

Since 2016, Al Shabaab's local commanders have felt confident enough to begin a series of military operations aimed at the military bases of AMISOM, Kenyan or Somali armed forces. In January, they assaulted the El-Adde compound, manned by the elite, by Somali standards, of the infantry units from Kenyan Defense Forces - KDF. Terrorists used VBIED and small units to force their way into the military zone and to inflict losses on a group of defenders (Raubo, 19.01.2016). In the following month, they also took control over a very important city of Merca because of its strategic location and a close proximity to the capital. Of course, like in every such a situation, $\mathrm{Al}$ Shabaab was not able to keep all the territorial gains for long; each offensive or even a single battle showed increased capabilities of this terrorist organization.

SCENARIOS - As some of the most important last year's events indicate, in 2017 Al Shabaab have regained their operational sources; this has happened because of a limited military pressure from AMISOM in 2015-2016, in conjunction with financial problems, some misunderstandings between political leaders from African states who are the members of the peacekeeping mission and, of course, because of the internal problems of Somali governments. However, a new potential trend in fighting a campaign against Al Shabaab, started earlier by the USA, can be seen. The external forces will focus their attention only on strikes on selected targets from terrorist organizations, without any long-term, holistic strategy to rebuild Somalia. Such a situation occurred before, after El-Adde battle in which (most likely) Kenyan air forces had attacked some of the Al Shabaab's camps. It is necessary to underline that the American Special Operation Forces - various SOF units, are present in Somali territory and perhaps even use the base in Mogadishu for a full spectrum of missions. This might be 
a modus operandi for Kenya or Ethiopia. However, it will be carried out at the expense of further weakening of some AMISOM operations. Perhaps there will also be much more air attacks on the targets connected to Al-Shabaab, both with conventional planes and unmanned aerial vehicles UAVs.

An open question is how Al Shabaab leaders could use the present problems of drought and famine in Somalia for their own strategic purposes in 2017. For instance, any imbalance within the external humanitarian aid might be some kind of a turning point for them. Local tribes could withdraw their support for the central government and this will create perfect circumstances for first - infiltration, and second - expansion of Al Shabaab, straight from the terrorists' sanctuaries to new lands which they lost after 2011. However, this is only one of many challenges faced by the central government in Mogadishu. Therefore, it is impossible for the government to use all its forces against them. Other problems include, for example, the threat of a new wave of piracy in the Gulf of Aden, the problematic relations between Somalia and Somaliland but also some other regions, etc.

For Al-Shabaab, 2017 will be a period of implementing and testing their new strategy in fights against their internal and external enemies. On one hand, they will do this based on stronger guerrilla warfare and their attempts to control and govern more territories. On the other hand, they will try to launch stronger terrorist campaigns in major cities like Mogadishu, using the methods they had already tried out not only in their past actions but also in Yemen or Syria. There is a need for the present emir of AlShabaab, Ahmed Umar aka Abu Ubaidah (Counter Extremism Project 1), to halt the creation of some kind of an internal opposition, based on the cooperation with Da'ish. Similarly to Afghanistan or Syria, the terrorists of Al Qaeda and Da'ish fight each other for power, money, and new recruits. Somalia is no exception; some struggles are even crueler in comparison to other regions.

\section{Egypt's Internal Instability}

Similarly to Somalia, most of the North African states have struggled not only with a terrorist threat but also with some others security challenges. Of course, the so-called Arab Spring and a series of rapid popular revolutions or armed uprisings after 20102011 were a turning point which has propelled a change in the structural vision of the regional order and, like in Libya, put this state on the brink of collapse and full internal division. Hence, in 2016 we witnessed certain continuity of same dangerous trends which might have a further impact not only on them but also on Europe. Generally, this issue is related to such problems as counterterrorism and the fight against Al Qaeda and Da'ish, border security, especially of the Libya-Egypt border, the potential level of rivalry between the regional state players, and the maritime security in strong migration crisis. There is also a question about how to deal with some new authoritarian governments formed after 2013, e.g. in Egypt, and whether the West will accept any forms of new potential authoritarian regimes in North Africa.

At the beginning, considering the strategic location of Egypt, all plans of a longterm stabilization of the North Africa's region need to be based on a strong cooperation 
with the rulers from Cairo. Unfortunately, this country's internal situation is far from a satisfactory security level. First of all, Egyptian armed forces, border guards and other security structures in 2016 were still involved in open warfare with terrorism on the Sinai Peninsula. It is important to mention that Sinai has never been a secure place and that this territory was an arena of a series of armed conflicts and disputes between Egypt and Israel. In the words of Z. Laub:

"Though the peninsula is a land bridge connecting Africa and Asia, historically it has
separated as much as joined them. The region's majority Bedouin population shares
closer historical and cultural ties to the Levant and Arabian Peninsula than the Egyp-
tian mainland" (Laub, 2013).

The most important jihadi player in this Egyptian region is, of course, Da'ish, also known as Wilayat or in English, the Sinai Province which, officially, constitutes a part of a self-styled caliphate, with the headquarters in Syria and Iraq. This structure uses a global brand of Bakr al-Baghdadi organization, adding some local aspects and enjoying the operational freedom. Formally new Wilayat was "established in late 2014 when the Sinai-based Salafist-jihadi group Ansar Bayt al-Maqdis (ABM) pledged its allegiance to the 'caliphate.' Previously, ABM had declared war on the Egyptian government following the 2013 overthrow of Egyptian President Mohammad Morsi" (AIPAC, 2016). A big publicity has been achieved by them after a November 2015 terrorist attack, against the civilian Russian airplane, carrying tourists from Sharm elSheikh. Because of it, some previously concealed by the government in Cairo security problems from Sinai suddenly became an international threat, adding to the wider struggles of the global antiterrorist coalition. This event also had a strong impact on a crucial, for an Egyptian state, branch of economy - tourism.

Nevertheless, a landscape of terrorist attacks in Sinai of 2015-2016 presented quite a systematic change in the tactic of a local Da'ish branch. Previously, they were assaulting military compounds, mainly some checkpoints, smaller military bases or security posts; most likely when the Egyptian government decided to send reinforcements to the conflict zone, further attacks on the military positions started to cost the local Da'ish too much. So, because of this, terror cells have shifted their tactic and a turned the vector of their offensive actions to killing innocent people: first, those Egyptians who had any connections with the central government or the structures whose functioning is necessary for efficient local administration. For instance, there was an assault on some ambulance workers in Sinai (Fouad, 2016).

In 2016 an important question was asked: can Da'ish Wilayat in the Sinai Peninsula spread their actions and spill the wave of violence among other Egyptian regions? Any major local activity of terrorists from Da'ish was targeted mostly on Bedouins and some other tribes which stood in the opposition to the government. Even if some violence in Sinai could be observed, it was contained within a limited area; obviously, it is easier to use the armed forces and other security forces there. But a new challenge for Egypt in 2016 was a potential growth of numerous assaults in cities, primarily in Cairo, and rising terror in some of the key tourist resorts. Last year was full of examples of such terrorist activity. For instance, in January three foreign tourists were stabbed at the Hurghada hotel (BBC, 9.01.2016); in December 2016, a bomb exploded near the major route to the Giza Pyramids, often used by those who visit the world her- 
itage monuments (Elgood, 9.12.2016). Also in the same year, terrorists tried to attack security forces more often, and this was not limited to Sinai. Simultaneously, Islamists targeted the Christian Coptic minority and the places connected to them and their religious practices (The Economist, 17.12.2016). For example, in December 2016, 25 Egyptians were killed in a bomb blast near St Mark's Cathedral in Cairo, one of the most important churches for Christians in this state (Al Jazeera, 11.12.2016).

Nevertheless, there are some doubts as to who was fully responsible for destabilization in Egypt. Of course, the easiest answer in such a situation was to name Da'ish and it is necessary to mention that this organization openly claimed responsibility for many incidents and larger attacks. There is also another, not so internationally well-known Hasm "Popular Resistance" terrorist organization. The group, which was formed in 2014, "first gained widespread attention in June 2015 when it claimed responsibility for the murder of the country's chief prosecutor, Hisham Barakat, in Cairo" (Shay, 19.03.2017). Hasm's case is important for an understanding of the general situation in Egypt since they have been linked to some waves of attacks, mostly against government workers and security personnel in 2016. They could assume a new role of a bridge between the radical fractions in the Muslim Brotherhood and Da'ish Wilayat Sinai, thus significantly expanding the terror-prone Egyptian territory and ipso facto creating a contingency for more occasions to use force in internal policy, all along referring to the suspicion towards the Islamists.

SCENARIOS - In the future, Da'ish or Hasm might become a very effective tool, both for the current government in Cairo and for right now the most important official illegal opposition in the form of the Muslim Brotherhood. For the president AbdelFattah al-Sisi and his armed forces or security institutions, any long-term operation in Sinai or counterterrorist operations against other terrorists is a visible sign that Egypt is a reliable partner for its international partners both from the West and from the Arabic Peninsula. Therefore, it will be possible for them to maintain some forms of the authoritarian rule without a strong external resistance. In addition to this, another matter is the Coptic Church's security problem, treating the present regime in Cairo as the last defense of religious diversity and a barrier between the modern world's standards and the radical Sunni ideology - approaching them to a useful status quo ante which existed in the Hosni Mubarak's years. For an internal situation in the country, such a continuity of domestic violence, strongly connected to terrorist activity, is an excuse for harsh law and the presence of the military units in major cities, thus blocking any occasion for a replay of some forms of popular uprisings, also in Cairo.

A continuation of the terrorist threat in Egypt gives many more possibilities for important foreign support (Sharp, 2017), mostly for some governmental projects, like building a security barrier on the border with Libya but also for other forms of empowering the armed forces, police, riot formations or even the most important - intelligence and counterintelligence. Still, a question remains how Egypt will benefit from a political and military cooperation with Saudi Arabia. A token of this relation is a participation of the Egyptian naval forces in a maritime blockade of Huthi in Yemen. In 2016, Egypt's government also approved a deal to hand over two Red Sea islands to Saudi Arabia. However, this plan might have a strong impact on the internal opposition in the country which may gain a great opportunity to invoke the nationalist concepts. 
Notwithstanding, that is a dangerous and risky policy for Abdel-Fattah al-Sisi. First, any terrorist incident in Egypt has had a real economic dimension to it, related to the fact that tourism is an important source of income. So, the best scenario for the Egyptian government assumes that any terrorist activity will be pushed back to the Sinai Peninsula but without any forms of danger to the resorts located along the Red Sea coastline or major places of mass interest, like Giza.

On the other hand, terror is acceptable for the Muslim Brotherhood and the supporters of the former president Mohamed Morsi. Any new casualties cause internal chaos and develop a sense of danger by weakening the security forces, as well as the President al-Sisi. However, the most important issue for them is the transfer of the security problems to the situation in the tourism sector because any shortcomings might have an impact on the state finance and an everyday life of the citizens. Of course, it is a well-known fact that pauperization brings more supporters to the political opposition and favors the occurrence of riots and demonstrations. Therefore, there is a high probability of a distributed violence in Egypt, even after curbing the activity of Da'ish.

\section{The Crawling Decay of Libya}

In hindsight, the situation in Libya in 2016 was perhaps even more complicated than in Somalia this same year. After 2011's revolution and the Western military intervention, the state plunged into a deep and strong internal division. Without Muammar Gaddafi, Libyans have never organized any efficient government which would be able to control at least the capital; different groups and fractions normally use power against each other as they try to control major cities and strategic branches of the natural resources infrastructure. Unfortunately, a strong presence of various terrorist organizations has an impact on an increasing level of violence in the country - robbery in huge weapons stores favored it. Therefore, Libya has become a typical example of a fragile state which projects its negative impact on almost all neighboring states - for instance, as a strategic part of the migration crisis from Africa to Europe because of a permanent lack of border controls.

In 2016 in Libya, two major contractual front lines could be observed. The first one was a vital part of anti-Daish or wider anti-terrorist struggles in the MENA region. On one side stood a loose coalition of militias controlled by moderate leaders; on the other side stood Da'ish Wilayat and Jihadist groups connected e.g. with Al Qaeda. Numerous Jihadi fighters have been present in Libya and have taken part in the fights since the beginning of the revolution against Muammar Gaddafi, mostly because the old regime in Tripoli has lost its control over prisons where they were detained. It is necessary here to underline that the former Libyan dictator started a cooperation with the Western intelligence agencies after 9/11 attacks and the US Iraq invasion, to fight the Islamist groups. The radical Islamists used internal chaos like in Syria or Iraq to create their own militia units: first, of course, to collaborate on a tactical field with the opposition in a struggle with Gaddafi and his allies. In this phase of the war, from the opposition's side, they were useful for their actions characterized by fanaticism. But, after their final victory, Islamists aimed at a creation of a strict and harsh religious 
state based on Sharia law. So, they never decided to disarm or join in the attempt of the unification process; they even started their own campaign against former coalition forces and the Western presence in Libya. A clear expression of this terror policy was an attack on the US consulate in Benghazi in September 2012 in which the US Ambassador was killed.

A new quality of terrorist activity came to Libya after 2014, with the beginning of the presence of the first formal Da'ish terrorist cells on this territory. Their origins are mostly related to the creation of the al-Battar Brigade in 2012 but only the Da'ish supporters, probably based on the patterns checked in Syria, started a new wave of Jihadist strategy. They wanted to link traditional terrorist operations targeted at Westerners and moderated forces with a classical territorial expansion based on paramilitary militia units. Since 2015, Da'ish have "built on an existing presence in the eastern city of Derna, a long-time jihadist hub, where groups active pledged allegiance to IS and took over local administration buildings" (BBC, 11.01.2016). Afterwards, they started a larger offensive which effected in, for example, taking control over Sirte in 2015. At the same time, Da'ish increased their presence in Libya and their enemies felt threatened so, mainly in 2016, varied Libyan internal fractions began a massive counteroffensive against the terrorist strongholds to retake Sirte and 150 miles of the Mediterranean coastline (Wintour, 5.12.2016). The main reason for so many Libyan groups to join in this operation was related to a potential threat that the Jihadists could gain an access to the country's natural resources which were, and still are, the pillars of Libyan economy and without them, no future government can build their power. After a heavy fighting with the Da'ish militias, moderate fractions seized the majority of important cities by the end of 2016. An important role in this victorious operation was played an external support, for instance from the US Air Force.

Still, any strategic conventional defeats of Da'ish in Libya in 2016 cannot cover the fact that there is still a significant number of functioning Jihadi organizations in Libya. Last year, the Ansar al-Sharia group was very active in Ganfuda, southwest Benghazi; heavy fighting with the troops from the so-called Libyan National Army (LNA) ensued. It is necessary to highlight that this terrorist organization is linked to a very influential regional Al Qaeda of Islamic Maghreb (AQIM) but they still keep the connection with al-Mourabitoun, a splinter group from AQIM. But besides Da'ish or AQIM supporters, the presence of other radical Salafist groups was noticeable in Libya in 2016 (Pack, 7.06.2017). They positioned themselves between the moderate forces and both terrorist organizations. For instance, some of the militia faithful to Sadeq alGhariani, Libya's Grand Mufti, could be seen as fully equipped Islamists with a radical vision of the future of Libya but without a strong external pressure to be delegitimized or destroyed. Because of it, perhaps, they are more dangerous right now than Da'ish, since they can use military tools based on paramilitary units, religious indoctrination, and political actions on weak public institutions.

An overall level of security and stability in post-revolutionary Libya depends not only on violent struggles with terrorists. The other field of rivalry is directly conjunct to a new map of aspirations of some political and military leaders. Several types of actors scramble for power in today's Libya: "armed groups; 'city-states', particularly in western and southern Libya; and tribes, which are particularly relevant in central and 
eastern Libya" (Toaldo, 2017). This multilayered political and military situation made ground for a concept of a new, strong-handed ruler, as the leader of Libya. Therefore, 2016 witnessed further efforts in this direction, mostly from the general Khalifa Haftar. Officially, he is a chief of the armed forces, loyal to the internationally recognized government of Libya - the so-called Libyan National Army 'LNA'. Practically, last year he led a very autonomous and independent policy regarding the internal situation in the country and in the field of relations with other foreign state actors. Obviously, what he used was a weak position of the Tripoli Libya's Government of National Accord 'GNA' to promote his leadership as a response to security problems. For instance, last year he had refused to cooperate with an internationally recognized government until they took control over the self-directed militias around the state (Irish, 20.05.2016). Simultaneously, the fights in Benghazi or Sirte continue and the influences in East Libya are being strengthened, thanks to a power center in Tobruk; while looking for his moves, he receives political and military support from Russia (The Guardian, 29.11.2016), mostly to balance the involvement of France and the US in the Libyan conflict.

SCENARIOS - To summarize, unfortunately, the events from 2016 do not promise anything good for the coming years. Of course, a hypothesis that Libya will become a safe-haven for major terrorists from $\mathrm{Da}$ 'ish after their general withdrawal from Syria and Iraq was much exaggerated because, with a collapse of Sirte, they suffered a loss of conventional strategic initiative. However, Da'ish and other Jihadist organizations will have an impact on the conflict in Libya since there have been many people who support radical Islam's vision for the state since 2011. Terrorists can also use strong divisions and differences among their political rivals in Libya to their advantage, mostly to maintain a net of smaller but dangerous cells and even militia formations, hiding their activities behind internal instability.

On one hand, further presence of Da'ish or Ansar al-Sharia will bring more foreign military operations in Libyan territory, including actions of the Special Operations Forces from the US or France and Egypt but, perhaps, also some problematic air strikes. It might have a direct impact on the local population and their attitude to the weak central government in Tripoli. This will mostly result in a rising negative reception of the western states and their allies on the ground. On the other hand, none of the major Libyan political actors wants to focus their forces on the fight with Jihadists due to the fear of weakening of the internal political position. However, in the next years, the greatest risk can be the penetration of local political institutions by some radical Islamists who have not had any direct connections with major terrorist organizations. Their long-term policy could block any moderate vision for the new Libya.

Political ambitions of, for instance, the general or even the marshal Haftar suggest that any UN-backed or other international forms of peaceful agreements can be very easily blocked by a form of an internal military coup. The long-term activity of numerous militias, in combination with a deepening economic crisis, create a very good opportunity to unify the state by the armed forces, creating an authoritarian regime. We cannot neglect a role of external players in Libyan policy. Not only from the West's perspective - the UK, France, Italy, the US, etc., a new balance of power in this North African state is an important part of their actions. For example, Libya's game is being played by the governments of Russia and Egypt right now. 
For Europe, the conflict in Libya has another important factor to consider; perhaps even more crucial than terrorism or destabilization of a role of a traditional natural resources exporter. It is the migration problem and the role of Libya's territory and its coastline in the generation of a new wave of people who try to cross the Mediterranean Sea. The former dictator Gaddafi fully controlled the migration paths leading to Italy because he knew well enough the true value of the fears of illegal immigrants in the West. Nonetheless, since 2011 the internal situation has opened new ways for smuggling people from Africa to Europe This was reflected in the 2015's crisis and after the EU agreements with Turkey; truth be told, Libya remains the biggest threat. This, in particular, is a chance for different Libyan militias to make a lot of money. Therefore, a lack of stabilization in Libya in 2017 will eventually shift to a bigger problem across the EU.

\section{AQIM Strategy for a Long-term War in Mali}

While the international community has generally been focusing on counterterrorism operations against Da'ish's supporters in the MENA region, other organizations have been regrouping and carrying out their own campaigns in Sahel and other parts of Africa. At the turn of 2015/16, such a new-old role was played by the Al Qaeda of Islamic Maghreb AQIM which developed new quality in its own activity. The first signal was clearly connected to the terrorist attack which happened at the end of 2015. AQIM, in cooperation with other group known better as the Al-Mourabitoun, stormed the Radisson Blu hotel in Bamako, the Malian capital. This attack "signaled a declaration of unity between both groups. Al-Mourabitoun has since taken the lead in AQIM operations, including a high-profile attack on a U.N. base in northern Mali" (Counter Extremism Project 2). In 2016, major non-Da'ish Jihadi organizations in North-West Africa ceased open competition initiated by the division in late 2012. The result of this was a series of deadly attacks in various states, like the one which happened in January 2016 in Burkina Faso or the other in March 2016 in Côte d'Ivoire.

The AQIM and its affiliated groups concentrate on three general operational fields. The first one is a typical guerrilla warfare against the local armed forces and other security formations. But of course, when the international coalition led by France decided to intervene in 2012 after the Malian coup d'état in this country, Jihadists targeted also foreign soldiers. In 2016, a series of ambushes in Mount Sammama area of Kasserine Governorate followed. Terrorists from the local branch of AQIM generally used an IED's to stop Tunisian or other military columns; after that, they used small arms to attack soldiers (Weiss 1, 1.09.2016). This tactic assumes an increase in the number of casualties among foreign military personnel deployed to Mali or neighboring states. Therefore, the United Nations Multidimensional Integrated Stabilization Mission in Mali MINUSMA, established in 2013, has become one of the most compromised operations in Africa. In 2016, the international forces from MINUSMA and other missions were repeatedly attacked by terrorists and suffered casualties. Methods used by AQIM or other groups are similar to those already observed in Iraq or Afghanistan. For instance, they fired Grad rocket against the French military compound located in Tim- 
buktu or stormed military positions with a combination of suicide bombers or vehicles and groups of riflemen. It is worth noting that in one such attack in Gao, a Chinese peacekeeper was killed.

The second form of terror activity, used in 2016 by AQIM, Al-Mourabitoun, etc. were attacks against civil targets, not directly connected with the military or security forces in the region. Until November 2016:

\begin{abstract}
"Mali and the wider West African region have seen at least 228 al Qaeda-linked attacks. Much of these have occurred in Mali's north, but over 40 have been in the southern part of the country. At least 19 incidents have occurred in neighboring states such as Niger, Burkina Faso, Algeria, and even the Ivory Coast. This represents a significant increase in the al Qaeda-led insurgency in northern Mali since last year, which has also spilled over the borders more frequently than the prior two years" (Weiss 2, 30.11.2016).
\end{abstract}

In this context, we saw a real danger for hotels, tourist attractions and the infrastructure related to the regional pillars of the economy.

Terrorists try to gain new sources of funding by typical criminal actions and this is the third form of activity of the AQIM and its affiliates. Therefore, Jihadists want to control smuggling routes in the entire region which are later used to redeploy e.g. people, cigarettes (like a famous terrorist leader - emir Mokhtar Belmokhtar), weapons etc. An important part of such activity is also kidnaping foreign citizens and forcing high ransoms from individuals, families, private sector or even states. In January 2016 some "missionaries were kidnapped in Mali and Burkina Faso, in October another (American) missionary/NGO worker was grabbed near Abalak, south of Agadez in Niger, on Christmas Eve 2016 a French NGO worker was abducted in Gao and a nun was also grabbed in Mali" (Sahara, 02.2017). A very important signal for the security situation in the region is that all forms of activity in 2016 revealed cross-border challenges that cannot be solved by a single state or even a multinational intervention in one state.

Therefore, mostly France tries to employ a holistic spectrum of military operations which will cover the entire region - Operation Barkhane is of a major importance here. It "began in August 2014, when France reorganized Operation Serval and a concurrent 28-year-old mission in Chad called Operation Épervier into a unified counterterrorism mission consisting of more than 3,500 French troops across Burkina Faso, Chad, Mali, Mauritania, and Niger" (Powell, 1.02.2016). They use a combination of their own kinetic, direct operations against some high valued targets together with the AQIM and other Jihadists, generally carried out by special operations forces supported by French helicopters and military or intelligence airplanes deployed into Sahel states. Also, training and assistance to support local formations of armed forces in their struggles with terrorists were provided. Unfortunately, no efficient military operations can solve the problems based on dysfunctional governments, borders disputes or the exclusion of the whole ethnic groups like Tuaregs in Northern Mali.

SCENARIOS - Since a new wave of violence and other forms of activity affiliated with the AQIM in Sahel in 2016, doubts have arisen regarding the long-term stability in the region. In contrast to Da'ish in Syria or Libya, the Jihadists from Mali and its neighboring countries are aware that they are not able to reach their goals fast 
right now if they use only conventional force; this is evident by the experience of Serval and Barkhane operations which left the AQIM to face the new tactic based on a combination of small operations, similar to Afghanistan, targeted at foreign troops and increasing the frequency of terrorist attacks against popular sites in major cities. Any new casualties among foreign troops, mostly from the West or even China, will have an impact on the attitude of the society and the politicians, and also on the will to continue the operations in Sahel. On the other hand, new high-profile attacks in cities, on the industrial infrastructure or tourist resorts will guarantee a better position in the global Jihadi movement in contrast to Da'ish and provide not only new recruits but also financial support to their organization.

For the international community, the situation in Mali and other regional states is a great opportunity to test a new approach to peacekeeping operations in the era of terror in Africa. These need to have a dual form because they cannot be constructed only on, even the most efficient, military action but also must involve a diplomatic form of discussion about the purposes of such regional destabilization. Unfortunately for the French foreign policy, it is more useful or plausible to accept some risky operations against terrorists but without a wider stabilization of Sahel; weaker Sahel states are better partners when it comes to the discussion about trade, natural resources or the presence of the foreign business in their territory. The present involvement of China in e.g. Mali can only further strengthen this view among the former colonial leaders, such as France.

\section{Boko Haram and Success without Final Victory}

However, in modern Africa there is also some other terrorist organization which actions symbolizing a highest level of brutality and cruelty, and it is Boko Haram. In 2009 , they officially began a military and terror campaign to impose Islamic government in Nigeria. Their initial strongholds were located mostly in the north-eastern parts of country, for instance in Yobe or Borno districts and of course Sambisa forest. But, during the following years they have expanded own operations beyond Nigerian territory and threatened civil population in Niger, Chad and Cameroon. In 2014, "according to data collected by the Global Terrorism Database (GTD), it was the world's most deadly terrorist entity" (Mahmood, 2017). But, Boko Haram became much more famous, on a global scale, since 2014 after the attack on Chibok school. After this wellknown hostage incident, most important world players, headed by US, put a strong pressure on government from Abuja to organized efficient counterterrorist operation against Boko Haram. This effect has been strengthened by information that Boko Haram and its leader Abubakar Shekau pledged allegiance in March 2015 to Da'ish.

Regarding to these events and because of repeated terrorist attacks in various parts of Nigeria central government focused more attention on military operations against Jihadists. Therefore in 2016 at least we saw some progress in fights mostly in Nigeria where armed forces and security agencies retook control over some Nigerian regions previously controlled by Boko Haram. They also tried to build local selfdefense system based on agreements with regional leaders whose were in opposition 
to Boko Haram. But, perhaps most visible turning point is dated on last part of 2016 when Nigerian forces started operation in Sambisa forest. So, in a place which had been a terrorist bastion for years and which was used to training and preparing attacks in the whole country (The Telegraph, 24.12.2016). Regarding to these events and because of repeated terrorist attacks in various parts of Nigeria central government focused more attention on military operations against Jihadists. Therefore in 2016 at least we saw some progress in fights mostly in Nigeria where armed forces and security agencies retook control over some Nigerian regions previously controlled by Boko Haram.

But last year a Nigerian Jihadist movement was weakened not only by efficient military campaigned but also by internal problems resulting from the power struggles. In August 2016, the crack became very obvious when the Daesh named Abu Musab al-Barnawi, as the new leader of Boko Haram. The long-time leader of the group, Abubakar Shekau, denied he had been replaced and vowed to continue the insurgency (Onuoha, 27.11.2016). Therefore, after 2016 present capabilities of divided organization is much lower than ever before.

But it's necessary to mentioned here that not only Nigerian government has bought during last years a lot of new equipment for army mainly to defeated terrorist and invest in own military capability. Positive signals came also from Chad or Cameroon which want to secure a situation on borderlands with Nigeria. Present fights against Boko Haram is strongly supported by some external partners. For instance, in 2016 US resumed professional training program as a part of strategy against the terror group and, part of the new deal the Obama administration entered with President Muhammadu Buhari (Olorunyomi, 12.02.2016). Like they are constantly cooperating with Chad on counterterrorism filed for example with cyclical special operations forces maneuvers Flintlock. And on the base of US AFRICOM build other forms of regional counterterrorism cooperation.

SCENARIOS - Hitherto activity of Boko Haram put this organization on the list of the most dangerous world terrorist groups in history. But their successful campaign of violence during the last years drew more attention on them from the states governments and international organizations. So, even despite the Nigeria didn't overcome major problems inside their military like the corruption, external and internal pressure was too strong not to start large scale counterterrorism operations against Boko Haram strongholds. Because of it Jihadists lost some previous operational capabilities and they were pushed into the strategic defensive. But unfortunately, they still have effective background to organize some attacks in Nigeria or in Cameroon. But they are characterized by a smaller magnitude and they are not so bloody than before. If present Nigerian, Chadian, or Cameroonian authorities will use a last year split inside Boko Haram they might have a great opportunity to marginalized this organization. And in long-term perspective fully retaking a permanent control over the most dangerous territories of their own countries. But any achievements may be lost very quickly without implementing some structural programs directed to local population and people who left territories previously controlled by terrorists. But after 2016, international community is much closer to defeat Boko Haram than to do this same in case of Al Qaeda or Da'ish. 


\section{BIBLIOGRAPHY}

Abu-Zaid A. (2017), South Sudan: aftermaths of 3 years of armed conflict, "thelancet.com," Vol. 389 , 11.02.2017.

ACLED (2015), Country Report: Central African Republic, “Armed Conflict Location \& Event Data Project".

African Research Bulletin (11.08.2015), Central African Republic: Timber Companies Fuel Conflict, "African Research Bulletin," Vol. 52, No. 7, 11.08.2015.

Africanews (2016), UN to intervene in border dispute between Gabon and Eq. Guinea, "Africanews," 16.11.2016, http://www.africanews.com/2016/11/16/un-to-intervene-in-border-dispute-between-gabon-and-eq-guinea// (21.05.2017).

Africareport (2014), CAR: AU troops give way to UN troops, "theafricareport.com," 16.09.2014, http://www.theafricareport.com/Central-Africa/car-au-troops-give-way-to-un-troops.html (18.05.2017).

AIP (2014), Ethnic Cleansing and Sectarian Killings in the Central African Republic, "Amnesty International Publications," London, p. 30.

AIPAC (2016), ISIS in the Sinai Peninsula, “AIPAC.org," http://www.aipac.org/-/media/publications/comms/mounting-threats-isis.pdf (7.06.2017).

Al Jazeera (2016), 25 killed by bomb blast near St Mark's Cathedral, "AlJazeera.com," 11.12.2016, http://www.aljazeera.com/news/2016/12/egypt-20-killed-bomb-blast-coptic-cathedral-161211093122198.html (7.06.2017).

BBC (11.01.2014), Profile: Central African Republic's Michel Djotodia, "BBC News," http://www. bbc.com/news/world-africa-21938297 (18.05.2017).

BBC (30.04.2014), Senegal's Casamance MFDC rebels declare a ceasefire, "BBC News," http:// www.bbc.com/news/world-africa-27221999 (21.05.2017).

BBC (09.01.2016), Egypt attack: Three tourists stabbed at Hurghada hotel, "BBC News," http:// www.bbc.com/news/world-middle-east-35268713 (7.06.2017).

BBC (11.01.2016), Guide to key Libyan militias, "BBC News," http://www.bbc.com/news/worldmiddle-east-19744533 (7.06.2017)

BBC (28.10.2016), Nigeria to spend \$10 bn to end conflict in oil-rich Niger Delta, "BBC News," http://www.bbc.com/news/world-africa-37797905 (20.05.2017).

BBC (9.12.2016), Who are Somalia's al-Shabab?, "BBC News," http://www.bbc.com/news/worldafrica-15336689 (7.06.2017).

BBC (24.04.2017), DR Congo's Kasai conflict: Voodoo rebels take on Kabila, "BBC News," http:// www.bbc.com/news/world-africa-39587896 (21.05.2017).

BBC (24.02.2017), South Sudan Country Profile, "BBC News," http://www.bbc.com/news/worldafrica-14069082 (19.05.2017).

Biar Ajak P. (2015), A Second Chance for South Sudan, "Foreignpolicy.com," 20.02.2015, http:// foreignpolicy.com/2015/02/20/a-second-chance-for-south-sudan/ (20.05.2017).

Buchanan E. (2016), Congo-Brazzaville: Who are the 'Ninja' militiamen fighting government forces?, "ibtimes.co.uk," 14.04.2016, http://www.ibtimes.co.uk/congo-brazzaville-who-areninja-militiamen-fighting-government-forces-1553037 (21.05.2017).

Call C. T. (2008), The fallacy of the "Failed State", "Third World Quarterly," Vol. 29, No. 8.

Call C. T. (2011), Beyond the "failed state": Toward conceptual alternatives, "European Journal of International Relations," Vol. 17, No. 2. 
CAR CSG (2011), Central African Republic: Country Study Guide: Volume 1 Strategic and Practical Information, International Business Publications, Washington DC.

CAR NRPP (2016), Central African Republic: National Recovery and Peacebuilding Plan 2017-21, Report by the European Union, World Bank Group, United Nations, https://eeas.europa.eu/ sites/eeas/files/car_main_report-a4-english-web.pdf (18.05.2017).

Cederman L., Min B., Wimmer A. (2005), The Ethnic Power Relations (EPR) dataset.

Clarke D. (2010), Africa: Crude Continent: The Struggle for Africa's Oil Prize, Profile books, London.

Clowes W. (2017), UN Renews Call for Negotiated Solution to Kasai Conflict in DRC, "Voanews. com," 25.04.2017, http://www.voanews.com/a/un-renews-call-for-negotiated-solution-tokasai-conflict-in-central-drc/3825046.html (21.05.2017).

Counter Extremism Project 1 (2017), Al-Shabab, https://www.counterextremism.com/threat/alshabab (7.06.2017).

Counter Extremism Project 2 (2017), Al-Mourabitoun, https://www.counterextremism.com/threat/ al-mourabitoun (7.06.2017).

Craze J. (2014), Contested Borders: Continuing Tensions over the Sudan-South Sudan Border, "Small Arms Survey," Graduate Institute of International and Development Studies, Geneva.

De Alessi B. (2015), Two Fronts, One War: Evolution of the Two Areas Conflict, 2014-15, "Small Arms Survey," Graduate Institute of International and Development Studies, Geneva.

de Simone S. (2013), Post-conflict decentralization: dynamics of land and power in Unity State - South Sudan, "UNISCI Discussion Papers," No. 33.

de Waal A. (2014), When kleptocracy becomes insolvent: Brute causes of the civil war in South Sudan, "African Affairs," Vol. 113, No. 452 (DOI: doi.org/10.1093/afraf/adu028).

Deschamps M., Jallow H. B., Sooka Y. (2015), Taking Action on Sexual Exploitation and Abuse by Peacekeepers: Report of an Independent Review on Sexual Exploitation and Abuse by International Peacekeeping Forces in the Central African Republic, 17.08.2015, http://www. un.org/News/dh/infocus/centafricrepub/Independent-Review-Report.pdf (18.05.2017).

Dickinson E. (2009), The trouble with “amnesty", "Foreignpolicy.com," 8.10.2009, http://foreignpolicy.com/2009/10/08/the-trouble-with-amnesty/ (21.05.2017).

Elgood G. (2016), Egypt security forces hit by two bombings in a single day, "Reuters," 9.12.2016, http:// www.reuters.com/article/us-egypt-violence-blast-idUSKBN13Y0SU?il=0 (7.06.2017).

Ferrie J. (2016), Caught between Juba and Khartoum: The double 'game' of China, "The East African," 1.08.2016, http://www.theeastafrican.co.ke/magazine/Caught-between-Juba-andKhartoum/434746-3325328-qot2lqz/index.html (20.05.2017).

Fouad A. (2016), Islamic State's Sinai branch shifts its strategy, “Al-Monitor,” 16.03.2016, http:// www.al-monitor.com/pulse/originals/2016/03/egypt-isis-terror-attacks-sinai-military-civilians.html (7.06.2017).

Found for Peace (2017), Fragile State Index, http://fundforpeace.org/fsi/ (7.06.2017).

Gaffey C. (2016), Why Eritrea's border with Ethiopia is a conflict zone, "Newsweek.com," 12.06.2016, http://www.newsweek.com/why-eritrea-border-ethiopia-conflict-zone-469739 (21.05.2017).

Giffen A. (2016), South Sudan, in: The Oxford Handbook of the Responsibility to Protect, (eds.) A. J. Bellamy, T. Dunne, Oxford University Press, Oxford.

Gramer R. (2016), French Peacekeeper Pull Out as New Violence Erupts the Central African Republic, "Foreignpolicy.com," 1.11.2016, http://foreignpolicy.com/2016/11/01/french-peacekeepers-pull-out-as-new-violence-erupts-in-the-central-african-republic/ (18.05.2017).

Guliyev F. (2014), Unpacking the Political Resource Curse : How Oil Fuels Personalism and Undermines Democratization, Doctoral dissertatin, Jacobs University. 
Hallmark T. (2017), Oil And Violence In The Niger Delta Isn't Talked About Much, But It Has A Global Impact, "Forbes," 13.02.2017, https://www.forbes.com/sites/uhenergy/2017/02/13/ oil-and-violence-in-the-niger-delta-isnt-talked-about-much-but-it-has-a-globalimpact/\#18ffc00d4dc6 (20.05.2017).

Herbert S., Dukhan N., Debos M. (2013), State fragility in the Central African Republic: What prompted the 2013 coup?, GSDRC, University of Birmingham, Birmingham.

Horadam N., Cleaves S., Sorhaindo J. (2015), Profile: Ahmed Abdi Godane (Mukhtar Abu Zubair), "Critical Threats," 6.01.2015, https://www.criticalthreats.org/analysis/profile-ahmed-abdigodane-mukhtar-abu-zubair (7.06.2017).

HSBA (2015), South Kordofan and Blue Nile Country Report, "Asylum Research Consultancy," 1.06.2016, http://www.ecoi.net/file_upload/90_1464788859_arc20160601-sudan-south-kordofan-blue-nile.pdf (21.05.2017).

Insight on Conflict (2009), Sudan: Conflict profrile, "insightsonconflict.org," August 2009, https:// www.insightonconflict.org/conflicts/sudan/conflict-profile/ (21.05.2017).

IRIN (2016), China's dangerous double game in the Sudans, "IRIN," 27.07.2016, https://www.irinnews.org/investigations/2016/07/27/china\%E2\%80\%99s-dangerous-double-game-sudans (20.05.2017).

Irish J. (2016), Libya's Haftar says won't work with unity government until militias disbanded, "Reuters," 20.05.2016, http://www.reuters.com/article/us-libya-security-haftar-idUSKCN0YB2FT (7.06.2017).

Isaacs-Martin W. (2016), Political and Ethnic Identity in Violent Conflict: The Case of the Central African Republic, "IJCV," Vol. 10, No. 1.

Johnson D. H. (2014), The Political Crisis in South Sudan, "African Studies Review," Vol. 57, No. 3 (DOI: 10.1017/asr.2014.97).

Kornprobst M. (2002), The management of border disputes in African regional subsystems: comparing West Africa and the Horn of Africa, "Modern African Studies," Vol. 40, No. 3.

Kriel B., Cruickshank P. (2016), Source: 'Sophisticated'laptop bomb on Somali plane got through X-ray machine, "CNN," 11.02.2016, http://edition.cnn.com/2016/02/11/africa/somaliaplane-bomb/index.html (7.06.2017).

Laub Z. (2013), Security in Egypt's Sinai Peninsula, "Council on Foreign Relations," 11.12.2013, https://www.cfr.org/backgrounder/security-egypts-sinai-peninsula (7.06.2017).

Lockhart Smith I. (2014), Conflict management in the Central African Republic: making genocide prevention work, "African Security Review," Vol. 23, No. 2 (DOI: 10.1080/10246029.2014.894925).

Louw-Vaudran L. (2014), Central Africa Republic's new president 'a fresh start', "Institute for Security Studies (ISS),” 24.01.2014, https://issafrica.org/iss-today/central-african-republics-newpresident-a-fresh-start (18.05.2017).

Mahmood O. (2017), Boko Haram in 2016: a highly adaptable foe, Institute for Security Studies, 7.02.2017, https://issafrica.org/iss-today/boko-haram-in-2016-a-highly-adaptable-foe (7.06.2017).

Mahr K. (2011), In Crumbling Sudan: Dodging Bombers with the Rebels of Blue Nile, "Time," 20.10.2011.

Malek M. (2016), Maritime border dispute looms in West Africa, "Interfax: Global Energy," 16.11.2016, http://interfaxenergy.com/gasdaily/article/22825/maritime-border-disputelooms-in-west-africa (21.05.2017).

Malik N. (2016), Bashir Comes in From the Cold, "Foreignpolicy.com," 31.07.2016, http://foreignpolicy.com/2016/07/31/europes-new-best-friend-in-africa-is-an-indicted-genocidal-warcriminal/ (21.05.2017). 
McCauley J. F. (2014), The Political Mobilization of Ethnic and Religious Identities in Africa, "American Political Science Review," Vol. 108, No. 4.

McCormick T. (2013), Can the World Still Make a Difference in the Central African Republic?, "Foreignpolicy.com," 3.12.2013, http://foreignpolicy.com/2013/12/03/can-the-world-stillmake-a-difference-in-the-central-african-republic/ (17.05.2017).

McCormick T. (2015), Unrest Paralyzes Humanitarian Effort in the Central African Republic "Foreignpolicy.com," 30.09.2015, http://foreignpolicy.com/2015/09/30/unrest-paralyzes-humanitarian-effort-in-the-central-african-republic/ (18.05.2017).

Meservey J. (2016), Somalia's Governance Problem, "Foreign Affairs," 15.05.2016, https://www. foreignaffairs.com/articles/somalia/2016-05-15/somalias-governance-problem (7.06.2017).

Miles T. (2017), South Sudan forces killed 114 civilians around Yei in six months: U.N., "Reuters," 19.05.2017, http://www.reuters.com/article/us-southsudan-un-idUSKCN18F0SR (20.05.2017).

MINUSCA (2017), United Nations Multidimensional Integrated Stabilization Mission in the Central African Republic, "un.org," http://www.un.org/en/peacekeeping/missions/minusca/ (18.05.2017).

Moran B. (2014), Hanging by a Thread, "Foreignpolicy.com," 22.09.2014, http://foreignpolicy. com/2014/09/22/hanging-by-a-thread/ (18.05.2017).

Morenne B. (2016), No Charges in Sexual Abuse Case Involving French Peacekeepers, "The New York Times,” 6.01.2016, https://www.nytimes.com/2017/01/06/world/africa/french-peacekeepers-un-sexual-abuse-case-central-african-republic.html?_r=0 (18.05.2017).

Munive J. (2014), Invisible Labour: The political Economy of Reintegration in South Sudan, "Journal of Intervention and Statebuilding," Vol. 8, No. 4 (DOI: dx.doi.org/10.1080/17502977.2 014.964451).

Mutiga M. (2016), Defiant Somalis condemn Al Shabaab beach attack, “The Guardian," 22.01.2016, https://www.theguardian.com/world/2016/jan/22/somalia-lido-beach-mogadishu-tweetlidopictures-alshabaab (7.06.2017).

Muvunyi F. (2016), Niger Delta's unending conflict, “Dw.com,” 16.06.2016, http://www.dw.com/en/ factbox-niger-deltas-unending-conflict/a-19326956 (20.05.2017).

Muvunyi F. (2016), Somalia: AMISOM plays down EU budget cut concerns, "DW," 30.05.2016, http://www.dw.com/en/somalia-amisom-plays-down-eu-budget-cut-concerns/a-19293643 (7.06.2017).

Mwakidue (2017), Mixed picture for Africa in 2017 Armed Conflict Survey, "Dw.com," 9.05.2017, http://www.dw.com/en/mixed-picture-for-africa-in-2017-armed-conflict-survey/a-38765465 (18.05.2017).

O'grady S. (2015), Is Khartoum Sending Weapons to Rebels in South Sudan?, "Foreignpolicy.com," 2.06.2015, http://foreignpolicy.com/2015/06/02/is-khartoum-sending-weapons-to-rebels-insouth-sudan/ (20.05.2017).

Oduah C. (2017), Trouble is Brewing in Nigeria’s Oil Country, "Foreignpolicy.com," 14.06.2016, http:// foreignpolicy.com/2016/06/14/trouble-is-brewing-in-nigerias-oil-country/ (21.05.2017).

Oilreviewafrica (2016), Drawing the line in border disputes, "oilreviewafrica.com," 28.12.2016, http://www.oilreviewafrica.com/exploration/exploration/drawing-the-line-in-border-disputes (21.05.2017).

Okello C. (2016), Kenya-Somalia maritime dispute: Whose sea is it anyway?, "rfi.fr," 20.09.2016, http://en.rfi.fr/africa/20160919-Kenya-Somalia-dispute-Whose-sea-it-anyway (21.05.2017).

Olorunyomi L. (2016), US resumes training of Nigerian troops for anti-terror war, "Premium Times," 12.02.2016, http://www.premiumtimesng.com/news/headlines/198338-us-resumestraining-nigerian-troops-anti-terror-war.html (7.06.2017). 
Onuoha F. C. (2016), Split in ISIS-Aligned Boko Haram Group, "Al Jazeera Centre for Studies," 27.11.2016, http://studies.aljazeera.net/en/reports/2016/10/split-isis-aligned-boko-haramgroup-161027113247008.html (7.06.2017).

Pack J. (2017), Mapping Libya's Jihadist, “Hate-speech.org," https://www.hate-speech.org/mappinglibyas-jihadists/ (7.06.2017).

Patinkin J., McCormick T. (2016), Renewed Violence in South Sudan Threatens Fragile Peace Agreement, "Foreignpolicy.com," 10.07.2016, http://foreignpolicy.com/2016/07/10/renewed-violence-in-south-sudan-threatens-fragile-peace-agreement/ (20.05.2017).

Pendle N. (2014), Interrupting the balance: Reconsidering the complexities of conflict in South Sudan, "Disasters," Vol. 38, No. 2.

Powell N. K. (2016), A Flawed Strategy in the Sahel, "Foreign Affairs," 1.02.2016, https://www. foreignaffairs.com/articles/west-africa/2016-02-01/flawed-strategy-sahel (7.06.2017).

Raubo J. (2017), Afrykańskie siły antyterrorystyczne na celowniku Al-Kaidy. Fiasko misji w Somalii?, "Defence24," http://www.defence24.p1/293880,afrykanskie-sily-antyterrorystyczne-nacelowniku-al-kaidy-fiasko-misji-w-somalii (7.06.2017).

Reeves E. (2016), Don't Forget Dafur, “The New York Times," 11.02.2016, https://www.nytimes. com/2016/02/12/opinion/dont-forget-darfur.html?_r=0 (21.05.2017).

Reuters (01.08.2016), Angolan rebels claim more casualties in oil-rich Cabinda, "Reuters.com," http://www.reuters.com/article/us-angola-war-cabinda-idUSKCN10C2AN (21.05.2017).

Reuters (08.08.2016), Death toll in Angola's oil-rich Cabinda rises to nearly 40, "Reuters.com," http://www.reuters.com/article/us-angola-war-cabinda-idUSKCN10J1BG (21.05.2017).

Sahara Overland (2017), Kidnappings, 02.2017, https://sahara-overland.com/kidnappings/ (7.06.2017).

Salau T. (2016), This is how Malawi and Tanzania can resolve their lake border dispute. "ventures," 7.12.2016, http://venturesafrica.com/malawi-tanzania-lake-border-dispute-why-the-unshould-rule-in-favour-of-malawi/ (21.05.2017).

Sharp J. M. (2017), Egypt: Background and U.S. Relations, “CRS,” 24.03.2017, https://fas.org/sgp/ crs/mideast/RL33003.pdf (7.06.2017).

Shay S. (2017), Egypt - The Hasm Terrorist Group, “ICT," 19.03.2017, https://www.ict.org.il/Article/1965/egypt-the-hasm-terrorist-group (7.06.2017).

Sky News (2015), Al Shabaab: Deadly Campaign Of Terror Attacks, "news.sky.com," 2.04.2015, http://news.sky.com/story/al-shabaab-deadly-campaign-of-terror-attacks-10365174 (7.06.2017).

Stewart F. (2012), Horizontal inequalities and conflict, in: Elgar Handbook of Civil War and Fragile States, (eds.) G. K. Brown, A. Langer, Edward Elgar Publishing, Cheltenham (UK), Northampton, MA (USA).

Sudan Tribune (30.07.2016), Machar says his troops may soon march on Juba, "Sudan Tribune," http://www.sudantribune.com/spip.php?article59772 (20.05.2017).

Targeted News Service (2014), The Central African Republic's Hidden Conflict, "Targeted News Service," Washington DC.

The East African (09.01.2017), Burundi picks a hill to launch fresh attack on Rwanda, https://www. theeastafrican.co.ke/news/Burundi-and-Rwanda-in-territorial-dispute-over-a-hill/25583510958-item-0-u1ap8a/index.html (21.05.2017).

The East African (21.01.2017), Fear of return of M23 rebels now fuels tensions in eastern DRC, http://www.theeastafrican.co.ke/news/Fear-of-return-of-M23-rebels-now-fuels-tensions--ineastern-DRC-/2558-3781826-38a3x7z/index.html (21.05.2017). 
The Economist (2016), Egypt is hit by terror attacks, "economist.com," 17.12.2016, http://www. economist.com/news/middle-east-and-africa/21711734-terrorism-egypt-compoundspresidents-problems-egypt-hit-terror (7.06.2017).

The Guardian (02.05.2017), There's more violence in Darfur now, not less, "The Guardian," https:// www.theguardian.com/world/2017/may/02/theres-more-violence-in-darfur-now-not-less (21.05.2017).

The Guardian (26.06.2016), Al Shabaablaunches fatal attack on Mogadishu hotel, "The Guardian," 26.06.2016, https://www.theguardian.com/world/2016/jun/25/al-shabaab-launch-attack-onmogadishu-hotel (7.06.2017).

The Guardian (29.01.2016), UN finds more cases of child abuse by European troops in CAR, "The Guardian," 29.01.2016, https:/www.theguardian.com/world/2016/jan/29/un-finds-morecases-of-child-abuse-by-european-troops-in-car (18.05.2017).

The Guardian (29.11.2016), Libyan general Khalifa Haftar meets Russian minister to seek help, "The Guardian," 29.11.2016, https://www.theguardian.com/world/2016/nov/29/libyan-generalkhalifa-haftar-meets-russian-minister-to-seek-help (7.06.2017).

The Herald (2014), Regime Change: France's objective in CAR, "The Herald," 14.01.2014, http:// www.herald.co.zw/regime-change-frances-objective-in-car/ (18.05.2017).

The Japan Times (03.10.2016), Ninja rebels attack Congo train, kill 14, including children, "japantimes.co.jp," http://www.japantimes.co.jp/news/2016/10/03/world/ninja-rebels-attack-congo-train-kill-14-including-children/\#.WSHJTmiGOUl (21.05.2017).

The Telegraph (2016), Boko Haram ousted from last remaining stronghold in the Sambisa forest, says Nigerian president, "Telegraph.co.uk," 24.12.2016, http://www.telegraph.co.uk/ news/2016/12/24/boko-haram-ousted-last-remaining-stronghold-sambisa-forest-says/ (7.06.2017).

Toaldo M. (2017), Political actors. A Quick Guide to Libya's Main Players, European Council on Foreign Relations, http://www.ecfr.eu/mena/mapping_libya_conflict (7.06.2017).

Uldom K. (2016), N'Delta Militants: More Groups Declare Ceasefire, "Reports Afrique news," 22.08.2016, http://www.reportsafrique.com/2016/08/ndelta-militants-groups-declare-ceasefire/ (20.05.2017).

UNHCR (2016), Some 13,000 displaced by Ninja clashes in Republic of Congo, "unhcr.org," 9.12.2016, http://www.unhcr.org/news/briefing/2016/12/584a77ab4/13000-displaced-ninjaclashes-republic-congo.html (21.05.2017).

UNMISS (2017), United Nations Mission in South Sudan, “un.org," https:/unmiss.unmissions.org/ background (20.05.2017).

USIP (26.09.2016), The Current Situation in the Central African Republic, "United States Institute of Peace,” 26.09.2016, https://www.usip.org/node/91931 (18.05.2017).

Vasselier A. (2016), Chinese Foreign Policy in South Sudan: the View from the Ground, "China Brief," Vol. 16, No. 13, 22.08.2016, https://jamestown.org/program/chinese-foreign-policyin-south-sudan-the-view-from-the-ground/ (20.05.2017).

Weiss C. (2016), Tunisian AQIM branch claims attack on troops in Kasserine, "Long War Journal," 1.09.2016, http://www.longwarjournal.org/archives/2016/09/tunisian-aqim-branch-claimsattack-on-troops-in-kasserine.php (7.06.2017).

Wintour P. (2016), Isis loses control of Libyan city of Sirte, "The Guardian," 15.12.2016, https://www. theguardian.com/world/2016/dec/05/isis-loses-control-of-libyan-city-of-sirte (7.06.2017).

Wrong M. (2016), Africa's Hottest Frozen Border Boils Over, "Foreignpolicy.com," 20.06.2016, http://foreignpolicy.com/2016/06/20/africas-hottest-frozen-border-boils-over-eritrea-ethiopia-war/ (21.05.2017). 
Ylönen A. (2014), Dwindling but surviving: South Sudan and external involvement in the current crisis, "Review of African Political Economy," Vol. 41, No. 141 (DOI: 10.1080/03056244.2014.907780).

Zambakari C. (2013), South Sudan and the nation-building project: Lessons and challenges, "International Journal of African Renaissance Studies - Mulit-, Inter- and Transdisciplinarity," Vol. 8, No. 1 (DOI: 10.1080/18186874.2013.834552).

Zartman I. W. (ed.) (2016), Casamance: Understanding Conflict 2016 Conflict Management and African Studies Programs Student Field Trip to Senegal, John Hopkins Schools of Advanced International Studies.

\begin{abstract}
The first part of this article provides an overview of the development of entrenched armed conflicts in Sub Saharan Africa which continue or have resurfaced in 2016. The author (JVdB) aims to expose the underlying causes and nature of the violent contestation by drawing of the works of C. T. Call in order to break open the black box of 'failed states' and analyze their legitimacy, capacity and security gaps separately. In addition the author will provide short scenarios of how these conflicts are likely to evolve in the short and medium-term and which (structural) factors will dominate these trends. The second part of this article (by JR) mainly aims at presenting the basic preconditions for the activities of the major terrorist organizations in Africa. With emphasis on the importance of the north-east and north-west regions of this continent in context of terrorist threats. Hence the initial focus was put on Somalia, which as a permanent fragile state remains under the increased influence of the Jihadist organization Al Shabaab, which is an organization with a high potential for increased capacity in the coming years. Next, was sketched out the situation in Egypt, considering, in essence, the activity of the so-called Islamic State in Sinai Peninsula. In this Analysis it also pointed to the intricate internal situation in modern Libya after so-called Arab Spring and international military intervention, where, despite earlier appearances, the terrorist threat was too much positioned, mostly by comprised to the internal conflict between the different Libyan political parties. Finally, efforts were made to illustrate the current terrorist activity in the Mali area, highlighting the importance of Al Qaeda branch AQIM and the situation in Nigeria where Boko Haram group operates.
\end{abstract}

Keywords: Al Shabaab, Al Qaeda of Islamic Maghreb, Angola, AQIM, Boko Haram, CAR, Congo (Brazzaville), Da ish, so-called Islamic State

\title{
KONFLIKTY ZBROJNE W AFRYCE: PAŃSTWA KRUCHE I ROSNĄCA NIESTABILNOŚĆ
}

\section{STRESZCZENIE}

W pierwszej części artykułu zaprezentowano przegląd wybranych konfliktów zbrojnych w Afryce Subsaharyjskiej, które toczyły się lub wybuchły ponownie w 2016 r. Autor (JVdB) postawił sobie za cel wskazanie przyczyn i charakteru brutalnych sporów, przede wszystkim poprzez odwołanie się do prac C. T. Call`a. Dążąc tym samym do rozpatrzenia dylematów związanych z "państwami upadłymi”, analizy problemu legitymizacji władzy, czy też poprzez określenie głównych możliwości oraz dysfunkcji z zakresu bezpieczeństwa, w szczegółowo rozpatrywanych przypadkach. Ponadto, Autor sformułował także scenariusze, starając się wy- 
wnioskować jak omawiane konflikty mogą ewoluować zarówno w perspektywie krótko jak i średnioterminowej. Próbując równocześnie odpowiedzieć na pytanie, które czynniki (strukturalne) zdominują ogólne tendencje zmian w regionie. W drugiej części artykułu (przez JR) postawiono sobie cel jakim jest przedstawienie uwarunkowań w zakresie aktywności najważniejszych organizacji terrorystycznych w Afryce. Ze szczególnym podkreśleniem znaczenia rejonu północno-wschodniego oraz północno-zachodniego tego kontynentu. Stąd wstępne skupienie uwagi na obszarze Somalii, która jako państwo słabe pozostaje pod wzmożonym wpływem tamtejszej dżihadystycznej organizacji Asz Szabaab, co więcej organizacji o dużym potencjale w zakresie wzrostu możliwości działania w kolejnych latach. Następnie dokonane zostało zarysowanie sytuacji w przypadku Egiptu, uwzględniając w głównej mierze aktywność tzw. Państwa Islamskiego na Synaju. Wskazano także na skomplikowaną sytuację wewnętrzną w Libii, gdzie jednak wbrew pozorom zagrożenie terrorystyczne było zbyt mocno pozycjonowane, chociażby względem wewnętrznego konfliktu pomiędzy zróżnicowanymi stronnictwami politycznymi. Finalnie spróbowano dokonać zobrazowania obecnej aktywności terrorystycznej w rejonie Mali, podkreślając znaczenie AQIM oraz w rejonie Nigerii, gdzie funkcjonuje Boko Haram.

Słowa kluczowe: Al Kaida Islamskiego Maghrebu, Al Shabaab, Angola, AQIM, Boko Haram, CAR, Da`ish, tzw. Państwo Islamskie 